\title{
The Effects of Medicinal Plants and Bioactive Natural Compounds on Homocysteine
}

\author{
Mohammad Amin Atazadegan ${ }^{1}$, Mohammad Bagherniya ${ }^{2,3,4, *}$, Gholamreza Askari ${ }^{2,3,4}$, Aida Tasbandi ${ }^{5}$ \\ and Amirhossein Sahebkar ${ }^{5,6,7, *}$ \\ 1 Department of Clinical Nutrition, School of Nutrition and Food Science, \\ Isfahan University of Medical Sciences, Isfahan 8174673461, Iran; atazadegan95@gmail.com \\ 2 Food Security Research Center, Isfahan University of Medical Sciences, Isfahan 8174673461, Iran; \\ Askari@mui.ac.ir \\ 3 Anesthesia and Critical Care Research Center, Isfahan University of Medical Sciences, \\ Isfahan 8174673461, Iran \\ 4 Department of Community Nutrition, School of Nutrition and Food Science, \\ Isfahan University of Medical Sciences, Isfahan 8174673461, Iran \\ 5 Applied Biomedical Research Center, Mashhad University of Medical Sciences, Mashhad 9177948564, Iran; \\ aidatasbandi@yahoo.com \\ 6 Biotechnology Research Center, Pharmaceutical Technology Institute, \\ Mashhad University of Medical Sciences, Mashhad 9177948564, Iran \\ 7 School of Pharmacy, Mashhad University of Medical Sciences, Mashhad 9177948954, Iran \\ * Correspondence: Bagherniya@yahoo.com or Bagherniya@nutr.mui.ac.ir (M.B.); \\ amir_saheb2000@yahoo.com or sahebkara@mums.ac.ir (A.S.)
}

Citation: Atazadegan, M.A.; Bagherniya, M.; Askari, G.; Tasbandi, A.; Sahebkar, A. The Effects of Medicinal Plants and Bioactive Natural Compounds on Homocysteine. Molecules 2021, 26, 3081. https://doi.org/10.3390/ molecules 26113081

Academic Editor: Maurizio Battino

Received: 19 March 2021

Accepted: 18 May 2021

Published: 21 May 2021

Publisher's Note: MDPI stays neutral with regard to jurisdictional claims in published maps and institutional affiliations.

Copyright: (c) 2021 by the authors. Licensee MDPI, Basel, Switzerland. This article is an open access article distributed under the terms and conditions of the Creative Commons Attribution (CC BY) license (https:/ / creativecommons.org/licenses/by/ $4.0 /)$.
Abstract: Background: Among non-communicable diseases, cardiovascular diseases (CVDs) are the leading cause of mortality and morbidity in global communities. By 2030, CVD-related deaths are projected to reach a global rise of 25 million. Obesity, smoking, alcohol, hyperlipidemia, hypertension, and hyperhomocysteinemia are several known risk factors for CVDs. Elevated homocysteine is tightly related to CVDs through multiple mechanisms, including inflammation of the vascular endothelium. The strategies for appropriate management of CVDs are constantly evolving; medicinal plants have received remarkable attention in recent researches, since these natural products have promising effects on the prevention and treatment of various chronic diseases. The effects of nutraceuticals and herbal products on CVD/dyslipidemia have been previously studied. However, to our knowledge, the association between herbal bioactive compounds and homocysteine has not been reviewed in details. Thus, the main objective of this study is to review the efficacy of bioactive natural compounds on homocysteine levels according to clinical trials and animal studies. Results: Based on animal studies, black and green tea, cinnamon, resveratrol, curcumin, garlic extract, ginger, and soy significantly reduced the homocysteine levels. According to the clinical trials, curcumin and resveratrol showed favorable effects on serum homocysteine. In conclusion, this review highlighted the beneficial effects of medicinal plants as natural, inexpensive, and accessible agents on homocysteine levels based on animal studies. Nevertheless, the results of the clinical trials were not uniform, suggesting that more well-designed trials are warranted.

Keywords: non-communicable diseases; cardiovascular disease; homocysteine; herbal medicine; medicinal plants

\section{Introduction}

In recent decades, we have experienced a shift in the disease burden towards noncommunicable diseases, which is likely due to the improved efficacy of treatments and lifestyle changes $[1,2]$. According to the World Health Organization (WHO), non-communicable diseases account for 75\% of global deaths in 2020; of these, cardiovascular diseases (CVDs) are the leading cause of mortality and morbidity in communities [3-5]. By 2030, CVD-related 
deaths are projected to reach a global increase of 25 million [6,7]. The documented studies show that non-communicable diseases are responsible for $\$ 7.28$ trillion loss from 2011 to 2025 , half of which is related to CVDs. It is estimated that a $10 \%$ reduction in CVDs will reduce the economic loss by $\$ 378$ billion over the years $[8,9]$. The known risk factors of CVDs include obesity, smoking, alcohol consumption, hyperlipidemia, hypertension, hyperhomocysteinemia, among others $[10,11]$. Homocysteine is a mediator in methylation cycle that acts as a cysteine and methionine precursor, a substrate for tissue folate recycling, and methyl receptor in choline catabolism [12-14]. Methionine is first converted to S-adenosylmethionine (SAM), which is, in turn, converted to S-adenosyl homocysteine $(\mathrm{SAH})$ in a reversible reaction. Subsequently, S-adenosine homocysteine breaks down into adenosine and homocysteine. In all tissues, 5-Methyltetrahydrofolate (as methyl group donor; in the liver, betaine acts as a methyl donor) and methylcobalamin (as coenzyme) are required to convert homocysteine to methionine with the help of vitamin B12. Homocysteine itself is first converted to cystathionine and then to cysteine (with the help of vitamin B6), which is finally excreted in the urine as sulfur-containing compounds or converted to taurine [15-17]. Homocysteine and its derivatives are bound to intracellular proteins and their presence in the blood may be due to their removal from the cells to be used by other tissues $[12,18,19]$. In 1962, the association between homocysteine and CVDs was established [20]. The normal homocysteine levels are considered to be less than 10 micrograms per liter. Hyperhomocysteinemia is defined as mild (12-30 micrograms per liter), intermediate (31-100 micrograms per liter), and severe (more than 100 micrograms per liter) [21,22]. In the general population, the prevalence of hypercysteinemia is approximately five to 10 percent and 30 to 40 percent in the elderly [23]. In population studies, an inverse relationship was found between homocysteine concentrations and vitamin B12 or abdominal aortic diameter in the elderly $[24,25]$. Several meta-analyzes have shown that hyperhomocysteinemia is a strong predictor of CVDs [26-30]. A five micromole per liter increase in blood homocysteine levels is associated with a $32 \%$ increase in myocardial ischemia and a 59\% increase in myocardial infarction [31]. Additionally, wild-type and mutant methyltetrahydrofolate increase the risk of cardiovascular disease by $25 \%$ and the homocysteine level by $16 \%$ [31]. Although the mechanism of action of homocysteine on blood vessels is not fully understood, it is thought to damage different layers of arteries [32]. Hyperhomocysteinemia has negative impacts on endothelial cells by affecting the production of nitric oxide, which regulates vascular tone [33-38]. It may also impair the maintenance of vascular homeostasis by interfering with the hydrogen sulfide signaling pathway that is closely related to nitric oxide [39]. Evidence suggests that hyperhomocysteinemia promotes inflammation of vascular endothelium by inducing inflammatory factors, such as interleukin-6, interleukin-8, and tumor necrosis factor alpha [40-42]. It is shown that high levels of homocysteine are associated with increased endoplasmic reticulum stress, which, in turn, leads to vascular inflammation [43] and oxidative stress in mice [44]. Additionally, homocysteine causes endothelial cell apoptosis, which is a primary sign of atherosclerosis [44,45]. In a study conducted in 2015, it was indicted that homocysteine metabolites (homocysteine thiolactone and N-homocysteine) could disrupt vascular homeostasis [46]. Another effect of homocysteine on the dysregulation of vascular homeostasis is through impairing the function of smooth muscle cells and inducing their proliferation [47-50]. Homocysteine causes arterial stiffness by the deposition of collagen in the vascular wall through the induction of connective tissue growth factor (CTGF). It also triggers the formation of aneurysm in coronary arteries by inducing the production of elastin degrading enzymes [51-54]. The preventive efforts are the best way of managing CVDs, and they are achieved by a proper lifestyle, including a balanced diet, and adequate physical activity [55], which may be not be favorable to some individuals. Although the strategies for the appropriate treatment of CVDs are constantly evolving; they are often ineffective and could have serious side effects $[55,56]$. Hence, the recent focus is on natural or low-risk supplements, such as herbal medicines or functional foods [57]. The protective effects of nutraceuticals on CVDs have been previously identified [58,59]. The term nu- 
traceutical was first coined in 1989 by Stephen Deflis. Nutraceuticals are defined as "foods or parts of a food that provide medical or health benefits including prevention or treatment of a disease" [60]. Nutraceuticals are substances that can be used instead of a medication as dietary supplements to control, prevent, or even treat diseases, such as CVDs [61]. These are known as food drugs and they are particularly helpful in patients who do not have access to a medication or for treatment of chronic diseases, such as osteoporosis, heart diseases, among others [62]. Recently, medicinal plants are becoming the focus of several researches, since these natural products have shown promising effects on the prevention and treatment of various diseases, particularly CVDs [63-66], diabetes mellitus [67-69], hypertension [70-72], and non-alcoholic fatty liver disease (NAFLD) [56]. The beneficial effects of herbal bioactive compounds on 3-hydroxy-3-methyl-glutaryl-coenzyme A reductase (HMG-CoA reductase) [73], Apolipoprotein B (Apo B) [74], and small dense LDL [74] have recently been reviewed. These are three important factors with unfavorable effects on CVDs. The effects of nutraceuticals and herbal products on CVDs/dyslipidemia have been previously studied. However, to our knowledge, the association between herbal bioactive compounds and homocysteine has not been reviewed in detail [63-66,75-79]. Thus, the main objective of this study is to address the efficacy of bioactive natural compounds on homocysteine levels, which was assessed through clinical trials and animal studies (Figure 1).

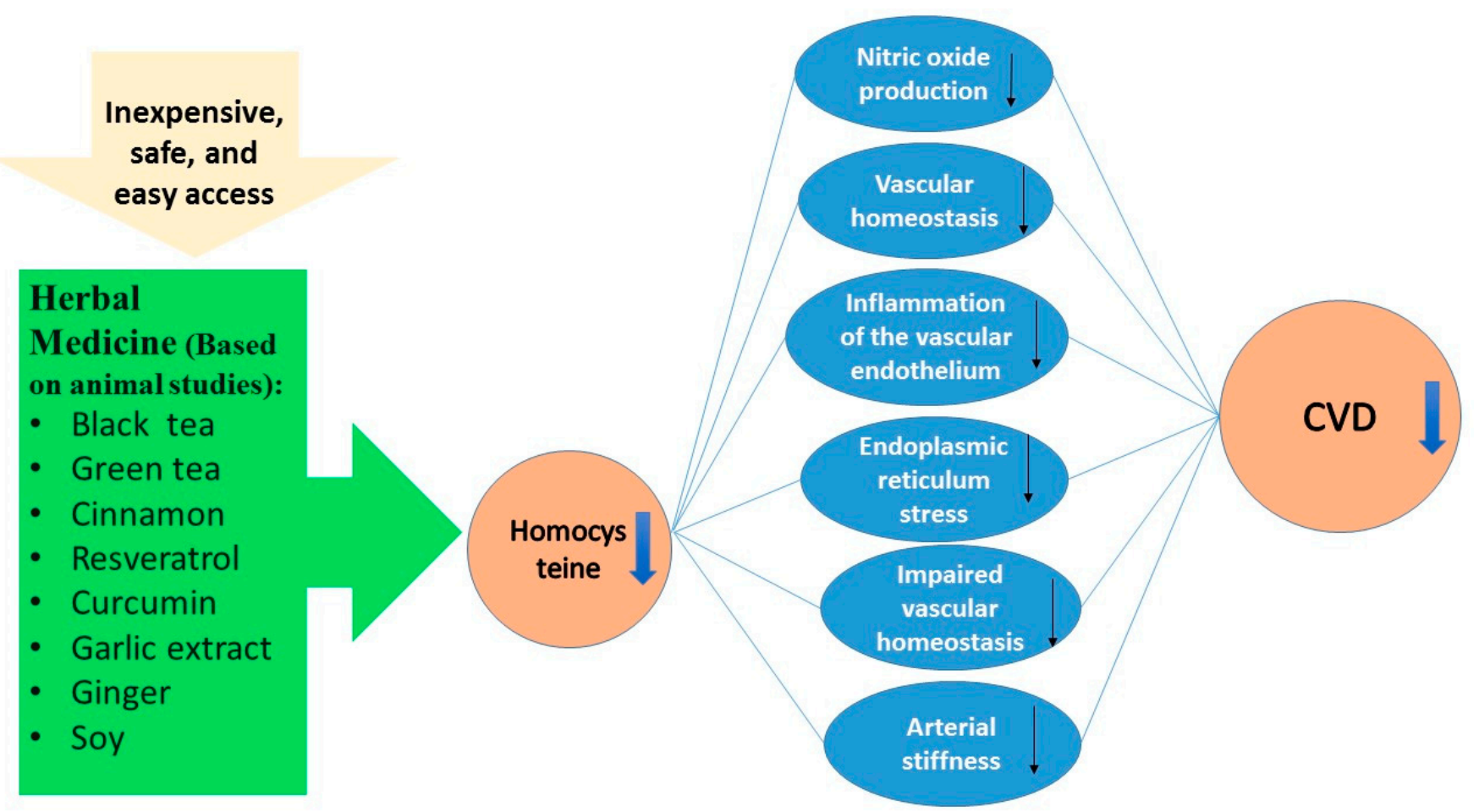

Figure 1. A schematic summary of pathways depicting the beneficial effects of herbal medicine on serum homocysteine (based on animal studies) and the possible mechanisms occurred after reduction in homocysteine level resulted in favorable outcomes; reduction in cardiovascular diseases (CVD).

\section{Results}

2.1. Plants

\subsubsection{Black Tea}

Tea is widely consumed around the world, and all the popular types of tea, like black tea, are manufactured from the leaves of Camellia sinensis (L.) Kuntze from Theaceae family. Several studies have shown that tea and its bioactive polyphenolic constituents have numerous beneficial effects on the prevention of diseases, like cancer, diabetes, arthritis, CVDs, stroke, and obesity [80-83]. These effects are due to antioxidative, anti-inflammatory, 
antihypertensive, cholesterol-lowering, antimicrobial, anticarcinogenic, neuroprotective, and thermogenic properties of the tea [83]. The favorable effects of tea on CVDs have been demonstrated in epidemiological studies and clinical trials [83]. Its effect on homocysteine level is one proposed mechanism. In one experiment, the rats were assigned into three groups: (1) Vehicle (saline), (2) angiotensin (Ang) II (50 ng/ $\mathrm{kg} / \mathrm{min}$.) to induce hypertension, and (3) Ang II + Black tea extract (BT) in which animals were given a $15 \mathrm{mg} / \mathrm{kg}$ /day of black tea extract (starting from Day 1 after Ang II pump insertion) for two weeks. Initially, angiotensin II infusion enhanced the plasma homocysteine level and it resulted in endoplasmic reticulum (ER) and oxidative stress, which, in turn, triggered endothelial dysfunction. However, black tea extract dramatically decreased the blood pressure and plasma homocysteine and, consequently, protected arteries of hypertensive rats from ER stress and endothelial dysfunction [84]. According to a clinical trial conducted by Hodgson et al., 20 adults with CAD were randomly assigned to four groups: (I) water and no meal, (II) black tea and no meal, (III) meal with water, or (IV) meal with black tea. The participants were asked to drink a cup of black tea (contained $2.2 \mathrm{~g}$ of tea leaves at times $0,1.5 \mathrm{~h}$, and $3 \mathrm{~h}$ ) or three cups of hot water with and without a meal (comprised a sausage, egg, bacon, McMuffins, and two hash browns). The total homocysteine was measured at baseline and $3.5 \mathrm{~h}$ after drinking black tea or hot water with and without a meal. In the end, an acute increase in homocysteine was observed after drinking black tea. Although the meal caused an acute decline in homocysteine level, it did not alter the homocysteine-raising effect of tea [85]. Similarly, in a randomized crossover study, 22 subjects were divided into two groups to drink $1250 \mathrm{~mL}$ black tea/d (five cups each containing $2 \mathrm{~g}$ tea leaves in $250 \mathrm{~mL}$ boiled water) or $1250 \mathrm{~mL}$ hot water/d for four weeks. For the next four weeks, the participants consumed the alternate drink. The findings demonstrated that black tea did not significantly alter the mean homocysteine concentrations [86]. Twenty healthy subjects in another crossover study received a diet low in polyphenols and they were randomly assigned into four groups of supplemented regimens: (I) $2 \mathrm{~g}$ chlorogenic acid (a compound found in coffee and black tea), (II) $4 \mathrm{~g}$ black tea solids (III) $440 \mathrm{mg}$ quercetin-3-rutinoside, or (IV) $0.5 \mathrm{~g}$ citric acid as a placebo. The duration of each trial was seven days (a four-week trial). The results showed that, after $4-5 \mathrm{~h}$ of supplementation, chlorogenic acid and black tea both raised total homocysteine concentrations in plasma when compared to the placebo. Quercetin-3-rutinoside exerted no effect on plasma homocysteine [87]. The different results between the animal and clinical studies might be due to the fact that, in a previous animal study, black tea was administered in experimentally hypertensive rats. It was suggested that homocysteine levels are reduced after the intake of black tea polyphenols in hypertension, which might be mediated and attributed to the promotion of homocysteine metabolism [84]. On the other hand, in the clinical trials, a small sample size of healthy subjects without hypertension were recruited, which might be a potential explanation for reporting the different results between animal and human studies [86,87]. In addition, it is suggested that tea and coffee, and their major constituents, such as polyphenols and caffeine, might increase homocysteine by acting as acceptors of methyl groups during the metabolism of methionine to homocysteine [86-89]. When considering these controversial findings and the fact that several studies suggest that tea consumption has a protective role against CVDs [90-92], there have been calls to conduct more studies in the future related to both the mechanistical and clinical aspects to explore the role of black tea on homocysteine.

\subsubsection{Green Tea}

Green tea is a non-fermented tea [93] that is traditionally used as a natural medicine. It is a rich source of polyphenols, mainly epigallocatechin-3-gallate (EGCG) (Figure 2) [94,95], which is proved to have favorable effects on neurological diseases, cancer, inflammation [94,96-99], and homocysteine-induced cerebrovascular injury [100]. In a study on adult male Wister rats, six groups were randomly assigned: (1st) normal laboratory diet, (2nd) $2.5 \mathrm{mg} / \mathrm{kg}$ body weight EGCG, (3rd) $5 \mathrm{mg} / \mathrm{kg}$ body weight EGCG, (4th) exposure to 4 Gy of $\gamma$ 
radiation, (5th) $2.5 \mathrm{mg} / \mathrm{kg}$ body weight EGCG + exposure to 4 Gy of $\gamma$ radiation, and (6th) $5 \mathrm{mg} / \mathrm{kg}$ body weight EGCG + exposure to $4 \mathrm{~Gy}$ of $\gamma$ radiation. The intervention was performed for three consecutive days in the 2nd and 3rd groups, and for two days in 5th and 6th groups. The third dose was administered for $30 \mathrm{~min}$. before irradiation. In rats that were pretreated with EGCG at a dose of 2.5 and $5 \mathrm{mg} / \mathrm{kg}$, plasma homocysteine was significantly decreased when compared to the first group. The homocysteine levels were significantly decreased in the second and third groups as compared to the first group [101].<smiles>O=C(O[C@H]1Cc2c(O)cc(O)cc2O[C@@H]1c1cc(O)c(O)c(O)c1)c1cc(O)c(O)c(O)c1</smiles>

Figure 2. Chemical structure of (-)-epigallocatechin gallate.

\subsubsection{Cinnamon}

Cinnamon (Cinnamomum verum J.Presl), a plant from the Lauraceae family, is mostly used as a spice [102]. It is a herbal medicine used for conditions, such as flatulence, amenorrhea, diarrhea, toothache, fever, leukorrhea, common cold, and headache $[103,104]$. Cinnamon and its main component, Cinnamaldehyde (Figure 3), have insulin sensitizer, antioxidant, and anti-inflammatory properties $[105,106]$. This herbal medicine was also traditionally recommended for the treatment of impotency, frigidity, dyspnea, eye inflammation, vaginitis, cough, rheumatism, neuralgia, and CVDs [107]. A two-phase clinical trial conducted by Amin et al. was conducted on 48 male albino rats for 5-8 weeks. Initially, hypercholesterolemia (the addition of $1 \%$ cholesterol powder, $0.25 \%$ bile salts, and beef tallow in a percentage of $4 \%$ to basal normal diet for 15 days) was induced. Subsequently, during the treatment period (starting from the third week and continued for six weeks), the hypercholesterolemic rats were divided into three subgroups (12 rats per group) according to the type of treatment. These regimens included HCD, HCD + Atorvastatin ( $0.2 \mathrm{mg} / \mathrm{kg}$ body weight), and HCD + cinnamon (C. zeylanicum Blume) ( $20 \mathrm{mg} / \mathrm{day} / \mathrm{rat})$. It was showed that cinnamon extract could reduce hypercholesterolemia and modulate oxidative stress and homocysteine [108].

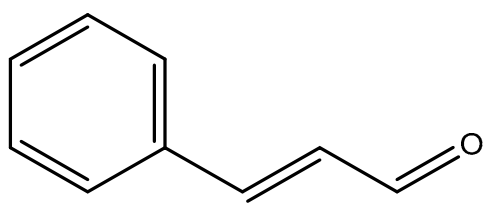

Figure 3. Chemical structure of cinnamaldehyde.

\subsubsection{Anthocyanin}

The word anthocyanin is derived from two Greek words, plant (Anthos) and blue (kianos), which are the most important pigments in vascular plants [109]. Like chlorophyll, they are natural pigments that are non-toxic, water-soluble, and widely present in plant cells [110]. Anthocyanins are the most colorful compounds among the flavonoids that are responsible for different colors found in many fruits, vegetables, and flowers [111,112]. 
They play essential roles in the management of CADs due to their high antioxidant effect $[113,114]$. In one clinical trial, 20 healthy female volunteers were randomly assigned into two groups to receive a placebo beverage or cranberry juice $(750 \mathrm{~mL} /$ day $(3 \times 250 \mathrm{~mL})$, which contained $2.80 \mathrm{mg} / \mathrm{L}$ anthocyanins) for two weeks. In the end, the plasma total homocysteine remained unchanged [115].

\subsubsection{Garlic Extract}

Garlic (Allium sativum L. Liliaceae) is a well-recognized medicinal plant. Several pharmacological implications of A. sativum and its organosulfur compounds, especially Allicin (Figure 4), include antibacterial, antiviral, antifungal, antiparasitic, anticancer, antiinflammatory, and cardiovascular protective properties [116-123]. It has beneficial roles on dyslipidemia, which lowers the total cholesterol concentrations by approximately $10 \%$ and favorably alters HDL/LDL ratios. Additionally, it acts as a mild anti-hypertensive that reduces blood pressure by 5-7\% [124]. A group of 60 subjects were randomly assigned to two groups: (I) intervention (received a daily capsule of aged garlic-extract (AGE) $(250 \mathrm{mg}$ ) plus vitamin-B12 $(100 \mu \mathrm{g})$, folic-acid $(300 \mu \mathrm{g})$, vitamin-B6 $(12.5 \mathrm{mg})$, and L-arginine $(100 \mathrm{mg})$ for 12 months) and (II) placebo. Finally, a reduced level of homocysteine was observed in the intervention group [125]. In a study conducted by Budoff et al., 65 patients with an intermediate risk for CVDs were randomly allocated to two groups: (I) the daily administration of a capsule containing AGE $(250 \mathrm{mg})$ plus Vitamin B12 $(100 \mu \mathrm{g})$, folic acid $(300 \mu \mathrm{g})$, Vitamin B6 $(12.5 \mathrm{mg})$, and L-arginine (100 mg) or (II) placebo. After one year of treatment, the homocysteine level was decreased in the AGE group [126]. In another experiment, 40 rats were employed to receive one of the following diets for six weeks (four groups of 10 each): (I) AIN-93G folic-acid sufficient (2 mg/ $\mathrm{kg}$ of diet); (II) AIN-93G folic-acid deficient; (III) AIN-93G folic-acid sufficient that was supplemented with AGE (4\% of diet, wt:wt); and, (IV) AIN-93G folic-acid deficient supplemented with AGE. The results showed that the addition of AGE to the severely folate-deficient diet decreased the total plasma homocysteine concentration by 30\% [127]. Based on a similar study, 23 patients with known CAD were randomly assigned to two groups: (I) received AGE $(4 \mathrm{~mL})$ or (II) received placebo for one year. Following intervention, the homocysteine levels showed no significant improvement [128]. In another randomized controlled trial (RCT), 30 postmenopausal women were randomly assigned to four groups: (1) placebo, (2) consumption of AGE ( $5 \times 65 \mathrm{mg}$ per week), (3) exercise ( $60 \%$ of maximum heart rate) and placebo, and (4) exercise and aged garlic extract. After 12 weeks, homocysteine was significantly decreased with intervention in the second and fourth groups [129]. Ried et al., conducted an RCT on 30 pediatric (aged 8 to 18 years old) patients who were administered $300 \mathrm{mg}$ AGE (three capsules/ daily) or placebo. After eight weeks of treatment, no significant difference was observed in homocysteine levels between groups [130]. In a similar $\mathrm{RCT}, 88$ uncontrolled hypertensive patients were given $1.2 \mathrm{gr}$ of AGE powder+ $1.2 \mathrm{mg}$ $S$-allylcysteine each day or placebo for 12 weeks. Following intervention, no significant change was detected in the homocysteine level in both groups [131].<smiles>C=CCSS(=O)CC=C</smiles>

Figure 4. Chemical structure of allicin.

\subsubsection{Ginseng}

Ginseng (Panax ginseng C.A.Mey., Araliaceae) is a medicinal plant with favorable pharmacological effects in cancer, diabetes, and CVDs, which also improves the immune system and central nervous system (CNS) function, relieves stress, and possesses antioxidant properties, and these benefits are mainly attributed to the presence of ginsenosides (Figure 5) [132-135]. A group of 40 wistar male rats were randomly assigned to one of the 
following four groups: (1st) control group (tap water), (2nd) Methionine (Met) $(1 \mathrm{~g} / \mathrm{kg}$ per day) and succinyl sulfathiazole (SSL) $(0.5 \mathrm{~g} / \mathrm{kg}$ per day), (3rd) ginsenosides total saponins (GTS) (Korean ginseng) (50 mg/kg every $12 \mathrm{~h}$ ), and (4th) Met + GTS + SSL. The homocysteine levels were measured within 30 and 60 days of the intervention, and they were found to be reduced in the fourth group as compared to the second group, whereas the third group had no significant change when compared to the first group [136].

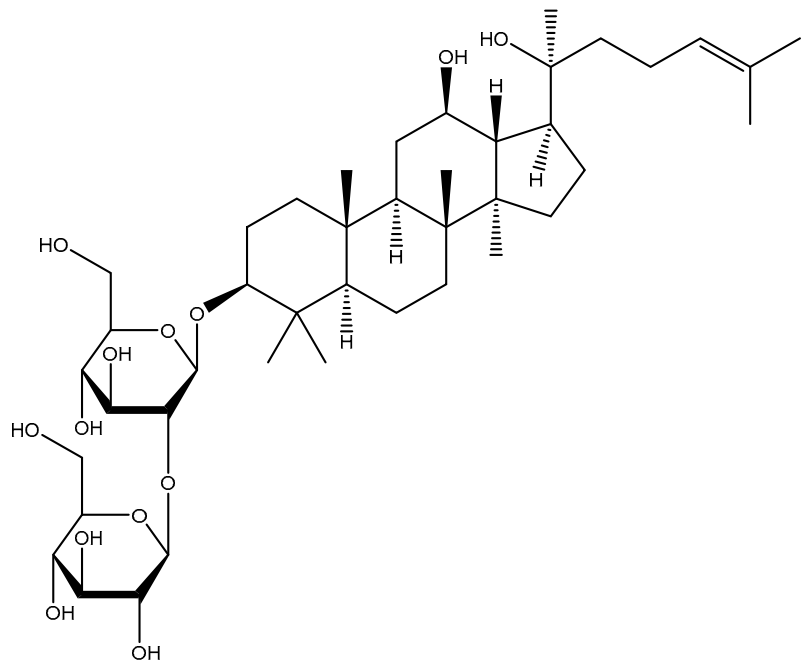

Figure 5. Chemical structure of ginsenoside $\operatorname{Rg} 3$.

\subsubsection{Chlorella}

Chlorella is a genus of approximately thirteen species of single-celled green algae belonging to the division Chlorophyta [137]. Chlorella pyrenoidosa, a single cell alga that is found in freshwater, has a rich content of chlorophyll and high concentration of nucleic acids, minerals, amino acids, dietary fiber, and vitamins. It has a strong cell wall that can only be digested by humans during a Dyno-Mill process. Studies showed that injection or oral intake of Chlorella following its cell wall destruction improves the immune function against infection and anti-cancer activity [138-143]. In study conducted by Merchant et al., 17 vegetarian/vegan (aged 26-57 years old) with a vitamin B12 deficiency were asked to add $9 \mathrm{gr} /$ day of C. pyrenoidosa to their routine diet for 60 days. The findings reveled that the homocysteine level was reduced by an average of $10 \%$ [144].

\subsubsection{Ginger}

Ginger (Zingiber Officinale Roscoe, Zingiberaceae) is a part of a family of plants, including cardamom and turmeric. It has a strong aroma due to the presence of gingerols (pungent ketones) (Figure 6). The rhizome part of the plant is traditionally used in Asia and tropical areas for fever, common cold, digestive problems, among others. Ginger is an appetite stimulant, and it is categorized by the U.S. FDA as a food additive [145]. Its beneficial effects on nausea/vomiting and arthritis have been previously reported [146-153]. In one experiment, 24 male Wistar rats were randomized into three groups: (1) non-diabetic control (tap water), (2) non-treated diabetic (tap water), and (3) ginger (Z. Officinale) extract treated diabetic $(50 \mathrm{mg} / \mathrm{kg}$ of hydroalcoholic ginger + tap water). After six weeks, the homocysteine level was notably enhanced in the second group when compared to the first group, whereas it was significantly declined in the third group as compared to the second group [154]. In another experiment by Akbari et al., 28 adult male Sprague Dawley rats were randomized into four groups: (1) control ( $2 \mathrm{~mL} /$ day corn oil), (2) ginger (Z. Officinale) ( $1 \mathrm{~g} / \mathrm{kg}$ body weight daily), (3) ethanol ( $4 \mathrm{~g} / \mathrm{kg}$ body weight daily), and (4) ethanol-ginger (Z. Officinale). After 28 days, the homocysteine level was significantly increased in the third group when compared to the first group, whereas it was significantly decreased in the fourth group as compared to the third group [155]. 


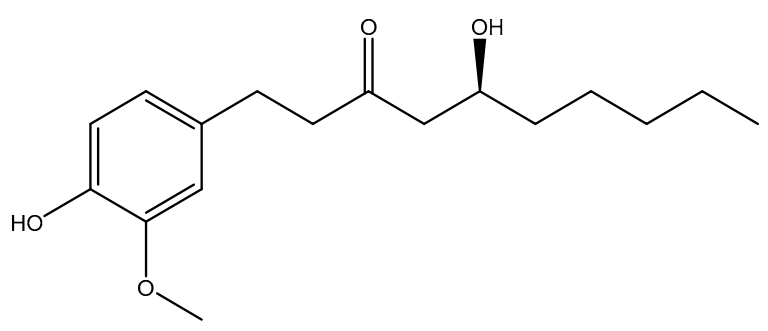

Figure 6. Chemical structure of [6]-gingerol.

\subsubsection{Soy}

Soybean (Glycine max (L.) Merr., Fabaceae) is a traditional plant that is native to East Asia, which is a good source of phytochemicals (e.g., isoflavones: daidzein, and genistein, Figure 7), fiber, and plant sterols [156-158]. Various studies have revealed its beneficial effects on blood lipids, CVDs, fertility, and menopause [159-161]. The result of a systematic review and meta-analysis (2016), which reviewed 19 randomized controlled studies, showed that Soy or isoflavones had no effect on homocysteine levels [162]. In a randomized cohort study, 87 healthy postmenopausal women were assigned to one of these groups: (1) $1200 \mathrm{Kcal}$ diet + exercise or (2) $1200 \mathrm{Kcal}$ diet + exercise + $200 \mathrm{mg}$ of Glycine max ( $80 \mathrm{mg}$ of soy isoflavone: $60.8 \mathrm{mg}$ of genistein, $16 \mathrm{mg}$ of daidzein, and $3.2 \mathrm{mg}$ of glicitein) for six months. Following intervention, the homocysteine level remained unchanged in both of the groups [163]. A group of 117 patients with hypercholesterolemia were also divided into three groups to receive: $15 \mathrm{gr} /$ day soy protein (containing SuproSoy from Solae, Saint Louis, MO, USA) and $25 \mathrm{gr}$ /day soy protein or placebo. No change in homocysteine level as compared to the baseline was found in all groups [164]. Similarly, in a cross over study on 34 postmenopausal women, the participants received $26 \pm 5 \mathrm{~g} /$ day of isolated soy protein (containing $44 \pm 8 \mathrm{mg}$ isoflavones per day) or $26 \pm 5 \mathrm{~g} /$ day of milk protein isolate for six weeks each and two weeks washout. The homocysteine level was not different between the two groups [165]. Forty patients on peritoneal dialysis were studied in a clinical trial; two groups were, as follows: received $28 \mathrm{gr} /$ day of textured soy flour (contained $14 \mathrm{~g}$ of soy protein) or followed their regular diet for eight weeks. The concentration of homocysteine had no significant difference between the two groups [166]. In another randomized crossover study on forty-one hyperlipidemic men and postmenopausal women, three groups were assigned to receive one of these regimens: (1) a low-fat dairy control diet, (2) low-isoflavone soy food diet (10 $\mathrm{mg}$ isoflavones/day), and (3) high- isoflavone soy food diet (73 mg isoflavones/day). Intervention was conducted for $3^{*}$ one months, allowing a two-week washout period between interventions. It was showed that the homocysteine level was lower in both isoflavones groups when compared to the control group [167]. A total of 55 postmenopausal women (aged 42-72 years) in a double blind clinical trial were randomly recruited to receive one of the four soy protein isolate treatments (40 g/d): (1st) normal phytate and isoflavone (Phytate: $0.78 \mathrm{~g}$ and Aglycone isoflavones: $84.6 \mathrm{mg}$ ), (2nd) normal phytate and low isoflavone (Phytate: $0.64 \mathrm{~g}$ and Aglycone isoflavones: $1.2 \mathrm{mg}$ ), (3rd) low phytate and normal isoflavone (Phytate: $0.22 \mathrm{~g}$ and Aglycone isoflavones: $85.5 \mathrm{mg}$ ), and (4th) low phytate and isoflavone (Phytate: $0.22 \mathrm{~g}$ and Aglycone isoflavones: $1.2 \mathrm{mg}$ ). After six weeks, the homocysteine levels were significantly reduced in soy protein normal phytate groups, whilst no significant change was detected in the soy protein normal isoflavone groups [168]. In another recent randomized crossover study, 89 postmenopausal women were randomly assigned to consume (1) two fruit cereal bar,s each including $25 \mathrm{mg}$ soy isoflavons (genistein:daidzein ratio of 2:1) or (2) only two fruit cereal bars with no isoflavones. The intervention was conducted for eight weeks with an eight-week washout. The results showed that homocysteine did not change in both groups [169]. In a recent double-blind RCT, 38 postmenopausal women complaining of insomnia were asked to either consume $80 \mathrm{mg}$ /day of isoflavones $(60.8 \mathrm{mg}$ of genistein, $16 \mathrm{mg}$ of daidzein, and $3.2 \mathrm{mg}$ of glicitein) daily or placebo for four months. Following intervention, the homocysteine showed no significant change in both groups [170]. Simi- 
larly, 30 female wild-type mice were randomly allocated to three groups: (I) the control group (modified standard maintenance chow), (II) soy group (55\% total energy), or (III) casein group ( $55 \%$ total energy). After 12 weeks, the homocysteine level was higher in casein group when compared to the control group, while the homocysteine level remained the same in the soy and control groups [171]. A total of 24 adult female Sprague Dawley rats were also randomized into four groups: (1) $2 \%$ cholesterol diet (2) $2 \%$ cholesterol diet + fresh soy oil, (3) $2 \%$ cholesterol diet + one-heated soy oil, and (4) $2 \%$ cholesterol diet + five-time-heated soy oil. After four months, $2 \%$ cholesterol diet + fresh soy oil significantly reduced the homocysteine level when compared to the others [172].<smiles>O=c1c(-c2ccc(O)cc2)coc2cc(O)ccc12</smiles>

Figure 7. Chemical structures of daidzein and genistein.

\subsubsection{Emblica Officinals (Amla)}

Emblica officinalis L. (Phyllanthaceae), which is known as Indian Gooseberry or Amla, is a fruit that has high levels of ascorbic acid (from 1100 to $1700 \mathrm{mg} / 100 \mathrm{~g}$ of fruit extract) and a high density of ellagitannins including emblicanin A (37\%) (Figure 8), emblicanin B (33\%), punigluconin (12\%), and pedunculagin. Amla is often consumed as a functional food due to its physiological features, such as radioprotection [173-175], antioxidant activity [176-180], hepatoprotection [181-184], cytoprotection [185,186], and hypolipidemic effects [176,187-189]. In a recent double-blind RCT, 98 patients affected with dyslipidemia were asked to either consume $500 \mathrm{mg}$ capsule of Amla extract (from Indian gooseberry) each day or placebo for 12 weeks. Following intervention, the homocysteine level did not change significantly in both groups [190]. Similarly, 17 uremic patients were selected to receive Amla extract tablets (300 mg, 50\% dextrin $+50 \%$ amla extract) four times a day. Based on the findings, the homocysteine level did not change after four months of intervention [191].

\subsubsection{Nuts}

Nuts have scant amounts of bioactive compounds (e.g., phytosterols, unsaturated FAs, fiber, protein, vitamins, calcium, magnesium, sodium, and potassium) and they are a good source of antioxidants [192-194]. In a study on 15 hypercholesterolemic (serum cholesterol level $>200 \mathrm{mg} / \mathrm{dl}$ ) adult males (aged 33-59 years), the patients received hazelnut (Corylus avellana L., Betulaceae) enriched diet (control diet (low-fat, low-cholesterol, and highcarbohydrate) $+40 \mathrm{~g} / \mathrm{d}$ hazelnut) for four weeks directly after four weeks of a control diet. Following intervention, no change in homocysteine level was detected between the groups [195]. In a two-phase single blind crossover study on 67 patients (serum total cholesterol $>5.2 \mathrm{mmol} / \mathrm{L}$ ), the participants first consumed low-fat, low-cholesterol diet for six weeks. On the second phase, two groups were randomly selected to either consume $64 \mathrm{~g} / \mathrm{d}$ walnut (Juglans regia L., Juglandaceae) with their diet or continue the same diet for six weeks. Finally, all of the patients were crossed over into the opposite treatment 
arm for another six weeks. The findings reveled no statistically significant change on the homocysteine levels [196].

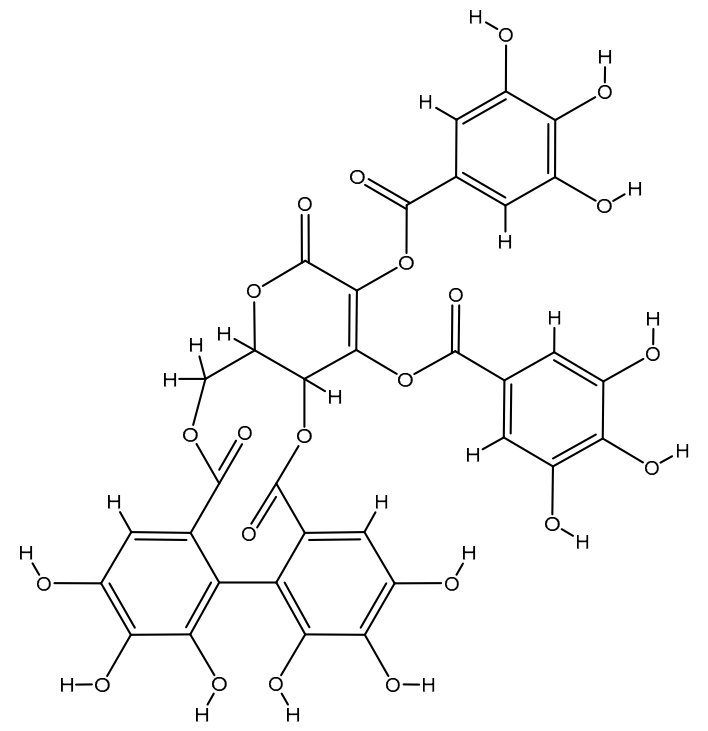

Figure 8. Chemical structure of emblicanin A.

\subsubsection{Olive Oil}

Olive oil, which is known as the elixir of health and youth, consists almost one-third to two-thirds of the fat used in the Mediterranean diet [197-201]. Many studies have shown its beneficial effects in improving heart diseases or cancer [202-205]. In one clinical trial, 121 obese $\left(\mathrm{BMI} \geq 35 \mathrm{~kg} / \mathrm{m}^{2}\right.$ ) adults (aged 18-65 years) randomly received one of these three diets: (I) $52 \mathrm{~mL} / \mathrm{d}$ extra virgin olive oil (EVOO), (II) traditional Brazilian diet (DieTBra), or (III) $52 \mathrm{~mL} / \mathrm{d}$ EVOO + (DieTBra). After 12 weeks, the homocysteine levels reduced in the EVOO group by nearly $10 \%$ (mean), whilst the homocysteine levels did not change significantly between groups two-by-two [206].

\subsection{Phytochemicals \\ 2.2.1. Berberine}

Berberine, a benzylisoquinoline alkaloid (Figure 9), is an active constituent in numerous medicinal plants with many pharmacological properties. It has been largely used in Ayurvedic and Chinese medicine for its antimicrobial, antiprotozoal, antidiarrheal, and antitrachoma activities. Several clinical and preclinical studies have indicated the promising effects of berberine on metabolic, neurological, and cardiological disorders [207-212]. In a study, healthy male rats (weighing 190-210 g) randomly received a standard diet or a high-fat diet (HFD) for 24 weeks. After eight weeks of feeding, rats that were fed with HFD were randomly assigned into two groups: (I) berberine (extracted from Coptis chinensis Franch.) (200 mg/kg/day) or (II) vehicle by gavage for 16 weeks ( $n=$ eight per each group). The results showed that the berberine consumption led to a significant reduction in serum homocysteine by about $60 \%$ when compared to the vehicle in rats fed with a HFD [213]. In a double-blind RCT, 31 diabetic patients were randomly assigned into two groups to receive Berberis vulgaris L. fruit extract $(3 \mathrm{~g} / \mathrm{d}$ ) (which contains the berberine alkaloid) or placebo for three months. No significant change was observed in the serum homocysteine level between the two groups [214]. 
<smiles></smiles>

Figure 9. Chemical structure of berberine.

\subsubsection{Curcumin}

Curcumin, a turmeric-derived polyphenol (Curcuma longa L., Zingiberaceae) (Figure 10), is known for its safety and medicinal properties against a variety of diseases [215-224]. It also has beneficial effects in metabolic syndrome and obesity $[225,226]$. In a recent doubleblind RCT, 22 obese men were administered a $500 \mathrm{mg}$ curcumin supplement (193 mg of curcuminoids in the form of $81.8 \%$ curcumin, $15.3 \%$ demethoxycurcumin (C20H18O5) (Figure 11), and 2.8\% bisdemethoxycurcumin(C19H16O4) (Figure 12) were infused into $60 \%$ soluble fiber from fenugreek to improve bioavailability) or placebo supplement (comprised of equal parts of soluble fiber from fenugreek) every day for 12 weeks. After intervention, the plasma homocysteine concentration was significantly reduced in the intervention group when compared to the placebo group [227]. In a clinical trial, female Wistar-Furth rats were randomly divided into low $\omega-3$ PUFA (LFO, $n=12$ ) and high $\omega-3$ PUFA (HFO, $n=12$ ) groups and they were further divided into three subgroups: LFO or HFO (controls), LFOE or HFOE (LFO or HFO plus ethanol, 35\% of dietary calories derived from ethanol), and LFOEC or HFOEC (LFOE or HFOE supplemented with curcumin $150 \mathrm{mg} / \mathrm{kg}$ body weight/day). All of these groups were pair-fed for eight weeks. Curcumin caused a significant increase in homocysteine thiolactonase activities as compared to the high $\omega-3$ PUFA and ethanol groups [228]. In a group of fifty healthy men who were randomly selected, a two month consumption of biscuits with a bioactive complex, such as organic selenium (115 mg), quercetin (6 g dried selenized onion), curcumin (1.3 g curcuma), and catechins ( $2 \mathrm{~g}$ green tea), was associated with decreased homocysteine levels [229]. In a clinical trial on 32 adult male Wister rats, four groups were selected: (1) control group (no injection), (2) vehicle of homocysteine $(2 \mu \mathrm{mol} / \mu \mathrm{L})$, (3) vehicle of curcumin $(50 \mathrm{mg} / \mathrm{kg})$, and (4) homocysteine-curcumin group. Curcumin was injected intraperitoneally once daily for 10 days, beginning five days prior to homocysteine intracerebroventricular injection. In the end, curcumin significantly reversed the behavioral and biochemical changes caused by exposure of homocysteine in the control mice. Similar to homocysteine, curcumin could be considered to be a therapeutic agent in preventing the progression of neurotoxicity [230]. A total of 50 female Sprague-Dawley rats (weighing 220-250 gr) were randomly divided to the following groups: (1) control (0.3 $\mathrm{mL}$ of the vehicle), (2) sham $(0.3 \mathrm{~mL}$ of the vehicle + surgery stress), (3) danazol treatment $(7.2 \mathrm{mg} / \mathrm{kg} \mathrm{BW})$, (4) curcumin treatment (48 mg/kg $\mathrm{BW})$, and (5) test (0.3 mL of the vehicle). After four weeks of treatment, no significant difference was observed between all groups [231].<smiles>COc1cc(/C=C/C(=O)CC(=O)/C=C/c2ccc(O)c(OC)c2)ccc1O</smiles>

Figure 10. Chemical structure of curcumin. 


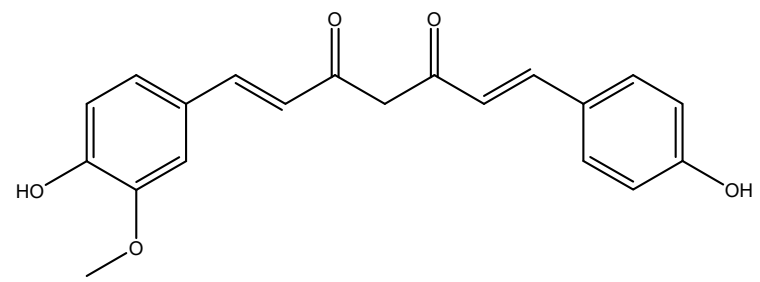

Figure 11. Chemical structure of Demethoxycurcumin.<smiles>O=C(/C=C/c1ccc(O)cc1)CC(=O)/C=C/c1ccc(O)cc1</smiles>

Figure 12. Chemical structure of Bisdemethoxycurcumin.

\subsubsection{Resveratrol}

Resveratrol (3,5,4'-trihydroxy-trans-stilbene) (Figure 13), a natural polyphenol that is found in numerous fruits and vegetables, has several properties, including anti-aging, anticancer, anti-inflammatory, and antidiabetic. Although the positive effects of resveratrol against selected cardiovascular risk factors have been a subject of debate over recent years $[232,233]$, there are numerous effects against oxidative stress, apoptosis, mitochondrial dysfunction, endothelial dysfunction, and angiogenesis that might still support the potential role of this phytochemical in the prevention of CVDs [234-236]. A total of 24 rats were randomly assigned to three groups: (I) control group (received standard rat food), (II) homocysteine group (received $1 \mathrm{~g} / \mathrm{kg}$ bodyweight/day methionine in drinking water), and (III) homocysteine + resveratrol group (received same amount of methionine + $20 \mathrm{mg} / \mathrm{kg}$ /day resveratrol intraperitoneally). After 30 days, the results indicated that the plasma homocysteine level was significantly reduced in a group that was treated with resveratrol [237]. In a study conducted by Noll et al., the mice were randomly divided into four groups and maintained on the following diets for three months: (I) control group (received standard rodent diet), (II) high methionine (received standard diet plus $0.5 \%$ L-methionine ( $36 \mathrm{mg} /$ day) in drinking water), (III) methionine/resveratrol (received high-methionine diet with $0.001 \%$ trans-resveratrol $(50 \mu \mathrm{g} /$ day) in the last month, and (IV) resveratrol (received standard diet with $0.001 \%$ trans-resveratrol in the last month). The findings showed that plasma total homocysteine concentration in high methionine group was four times higher than the control group. In the methionine/resveratrol group, plasma total homocysteine levels were non-significantly increased when compared to the methionine group. However, in methionine/resveratrol group plasma homocysteine levels were 1.3 times higher as compared to the methionine group. Additionally, in the resveratrol group, the homocysteine levels were significantly increased by $1.7(\mathrm{uM})$ when compared to the control group. Based on these results, resveratrol had detrimental effects on homocysteine levels [238]. Similarly, an experiment was performed on 30 female rats that were randomly allocated to three groups (I) control group, (II) potassium bromate group $\left(\mathrm{KBrO}_{3} 80 \mathrm{mg} / \mathrm{kg}\right)$, and (III) resveratrol $\left(33 \mathrm{mg} / \mathrm{kg}\right.$ four times a week) $+\mathrm{KBrO}_{3}$ $(80 \mathrm{mg} / \mathrm{kg})$. These treatments were continued for five weeks. The findings demonstrated that the serum homocysteine levels in the resveratrol+ $\mathrm{KBrO} 3$ group were significantly lower than the control group [239]. According to a study conducted by Schroecksnadel et al., peripheral blood mononuclear cells (PBMC) were isolated from healthy volunteer blood donors by density centrifugation. In order to examine the effects of resveratrol on PBMCs, the cells were either pre-incubated with 10-100 mM resveratrol or stimulated with mitogens after $30 \mathrm{~min}$., or resveratrol was added $2 \mathrm{~h}$ after stimulation. The cells were incubated at $37^{\circ} \mathrm{C}$ in $5 \% \mathrm{CO}_{2}$ for $72 \mathrm{~h}$ and supernatants were harvested by centrifugation and then frozen at $-208{ }^{\circ} \mathrm{C}$ until measurement. The results showed that unstimulated PBMCs produced small amounts of homocysteine and pretreatment of unstimulated cells 
with 10-100 $\mathrm{mM}$ resveratrol only slightly decreased the homocysteine production of resting cells [240].<smiles>Oc1ccc(/C=C/c2cc(O)cc(O)c2)cc1</smiles>

Figure 13. Chemical structure of resveratrol.

\subsection{Other}

\section{Soluble Fiber}

Water-insoluble fibers enhance the stool bulk and improve bowel movements. The viscous or gel-forming fibers (e.g., gums, mucilages, pectins, algal polysaccharides, some hemicelluloses, and some storage polysaccharides) are water soluble. Good sources of water-soluble fiber include oats, dried beans, barley, some vegetables, and fruits [241,242]. The positive effects of soluble fibers on cardiac diseases, hyperlipidemia, diabetes mellitus, insulin resistance, and obesity are well known [243]. In a double-blind randomized parallel controlled study, 29 overweight men (aged 20-69 years, BMI: $25-35 \mathrm{~kg} / \mathrm{m}^{2}$ ) were asked to consume $3 \mathrm{~g}$ soluble fiber every day or placebo for 12 weeks along with a carbohydrate restricted diet and standard daily multivitamins. In the end, the homocysteine level did not significantly increase in the fiber group as compared to the placebo group [244]. A total of 119 subjects were randomly recruited to two groups: (I) multivitamin and $4 \mathrm{~g}$ soluble fiber or (II) placebo. After eight weeks of intervention, the homocysteine levels were significantly reduced in the fiber blend group when compared to the placebo group [245].

\section{Conclusions and Future Perspective}

This review demonstrated that medicinal plants and herbal bioactive compounds have promising effects on reducing the homocysteine levels. According to the clinical trials, resveratrol and curcumin had favorable effects on serum homocysteine levels, whilst the results regarding other compounds were inconclusive (Table 1). In some of the previous studies, homocysteine was evaluated as a secondary outcome, and its effects on treatment or prevention of diseases were not elucidated. Moreover, factors, which included small sample size, diverse population in terms of age, being healthy or having underlying chronic diseases, different herbs with dissimilar dosages, and different duration of interventions, made it difficult to draw a strong evidence-based conclusion. Based on almost all animal studies, medicinal plants showed promising effects on homocysteine. Black and green tea, cinnamon, resveratrol, curcumin, garlic extract, ginger, and soy significantly reduced the homocysteine concentrations (Table 2). Altogether, this review highlighted the beneficial effects of medicinal plants as natural, inexpensive, and accessible agents without any considerable adverse effects on homocysteine levels. Nevertheless, the results of the clinical trials were not uniform, which suggested that more well-designed comprehensive clinical trials are warranted. 
Table 1. The effects of herbal bioactive compounds on homocysteine levels according to clinical trials.

\begin{tabular}{|c|c|c|c|c|c|c|c|}
\hline Number & Author, Year & Agent & Dose per Day & Treatment Duration & Subjects & Main Outcome(s) & $\begin{array}{l}\text { Final Effects of Nutraceuticals on } \\
\text { Homocysteine Level }\end{array}$ \\
\hline 1 & Hodgson et al., 2007 [85] & Black Tea & $2.2 \mathrm{~g}$ tea leaves & $3.5 \mathrm{~h}$ & Adults with CAD & $\begin{array}{l}\text { Black tea significantly increased plasma } \\
\text { homocysteine levels }\end{array}$ & $\uparrow$ \\
\hline 2 & Hodgson JM et al., 2003 [86] & Black Tea & $2 \mathrm{~g}$ tea leave $/ 250 \mathrm{~mL}$ boiled water & 12 weeks & Healthy subjects & $\begin{array}{l}\text { Black tea did not significantly alter mean } \\
\text { homocysteine concentrations }\end{array}$ & No effect \\
\hline 3 & Olthof MR et al., $2001[87]$ & Black tea & $4 \mathrm{~g}$ black tea & 4 weeks & Healthy subjects & $\begin{array}{l}\text { Black tea raised total plasma homocysteine } \\
\text { concentrations }\end{array}$ & $\uparrow$ \\
\hline 4 & Duthie et al., 2006 [115] & Anthocyanins & $750 \mathrm{~mL} /$ day cranberry juice $(2.80 \mathrm{mg} / \mathrm{L}$ anthocyanins $)$ & 2 weeks & Healthy volunteer females & $\begin{array}{l}\text { Cranberry juice had no effect on plasma homocysteine } \\
\text { levels }\end{array}$ & No effect \\
\hline 5 & Ahmadi N et al., 2013 [125] & Garlic extract & $\begin{array}{l}\text { Aged garlic extract (AGE) } 250 \mathrm{mg}+\mathrm{B} 12100 \mu \mathrm{g}+ \\
\text { B9 } 300 \mu \mathrm{\mu g}+\mathrm{B} 612.5 \mathrm{mg}+\mathrm{L} \text {-arginine } 100 \mathrm{mg}\end{array}$ & 12 months & Healthy subjects & $\begin{array}{l}\text { Garlic extract plus other supplements reduced } \\
\text { homocysteine level }\end{array}$ & $\downarrow$ \\
\hline 7 & Budoff MJ et al., 2004 [128] & Garlic extract & $4 \mathrm{~mL}$ & 1 year & Patients with CAD & $\begin{array}{l}\text { Garlic extract did not significantly improve } \\
\text { homocysteine level }\end{array}$ & No effect \\
\hline 8 & Seo DY et al., 2012 [129] & Garlic extract & $5 \times 65 \mathrm{mg}$ per week & 12 weeks & 30 postmenopausal women & Homocysteine was significantly decreased & $\downarrow$ \\
\hline 9 & McCrindle BW et al., 1998 [130] & Garlic extract & $3 \times 300 \mathrm{mg}$ per day & 8weeks & 30 pediatric $(8$ to 18 years old) & No significant difference between the groups & No effect \\
\hline 10 & Ried Ket al., 2016 [131] & Garlic extract & $1.2 \mathrm{~g}$ powder per day $+1.2 \mathrm{mg}$ S-allylystteine & 12 weeks & 88 uncontrolled hypertensive patients & No significant differences between the groups & No effect \\
\hline 11 & Merchant RE et al, 2015 [144] & Chorella & $9 \mathrm{~g}$ per day & 60 days & 17 vegetarian or vegan & Homocysteine level decreased by an average of $10 \%$ & $\uparrow$ \\
\hline 12 & Llaneza P et al., 2011 [163] & Soy & $80 \mathrm{mg}$ of soy isoflavone & 6 months & 87 healthy postmenopausal women & No change in both groups & No effect \\
\hline 13 & Heie LH et al, 2005 [164] & Soy & 15 or $25 \mathrm{~g}$ of soy protein & 8 weeks & 117 Hypercholesterolemic patients & No change in all groups & No effect \\
\hline 14 & Greany K et al,, 2008 [165] & Soy & $26 \pm 5 \mathrm{~g} /$ day of soy isolated protein & $2 \times 4$ weeks +2 weeks washout & 34 postmenopausal women & No change between both groups & No effect \\
\hline 17 & Hanson LN et al., 2006 [168] & Soy & $40 \mathrm{~g} /$ day soy protein isolate & 6 weeks & 55 postmenopausal women & $\begin{array}{l}\text { homocysteine was significiantly reduced in soy protein } \\
\text { normal phyytate group, while no significant change } \\
\text { was detected in soy protein normal isoflavone group }\end{array}$ & $\begin{array}{c}\text { soy protein normal phytat: } \\
\downarrow \\
\text { soy protein normal isoflavone: } \\
\text { no effect }\end{array}$ \\
\hline 18 & Reimann M et al., 2006 [169] & Soy & $50 \mathrm{mg}$ soy isoflavone & 8 weeks & 89 postmenopausal women & Homocysteine level did not change in both groups & No effect \\
\hline 19 & Brandao LC et all, 2009 [170] & Soy & $80 \mathrm{mg}$ soy isoflavone & 4 months & 38 postmenopausal women & Homocysteine level did not change in both groups & No effect \\
\hline 20 & Upadya H et al., 2019 [190] & Amla & $500 \mathrm{mg}$ capsule of Amla extract & 12 weeks & 98 patients with dyslipidemia & $\begin{array}{l}\text { Homocysteine level did not change significantly } \\
\text { between the groups }\end{array}$ & No effect \\
\hline 21 & Chen T-S et al., 2009 [191] & Amla & $\begin{array}{l}\text { amla extract tablets ( } 300 \mathrm{mg}, 50 \% \text { dextrin }+50 \% \text { amla } \\
\text { extract) four times a day }\end{array}$ & 4 months & 17 uremic patients & Homocysteine level did not change in subjects & No effect \\
\hline 22 & Mercanlıgil Set al, 2007 [195] & Nut & $40 \mathrm{~g} /$ day hazeinut & 8 weeks & 15 hypercholesterolemic patients & $\begin{array}{c}\text { Homocysteine level did not change between the } \\
\text { groups }\end{array}$ & No effect \\
\hline 23 & Morgan Jet al., $2002[196]$ & Nut & $64 \mathrm{~g} /$ day walnut & 18 weeks & $\begin{array}{c}67 \text { patients (serum total cholesterol }> \\
5.2 \mathrm{mmol} / \mathrm{L})\end{array}$ & No statically significant effects were observed & No effect \\
\hline 24 & Rodrigues APdS et al., 2020 [206] & Olive oil & $52 \mathrm{~mL} / \mathrm{d}$ EVOO & 12 weeks & 121 obese adult subjects & $\begin{array}{l}\text { Homocysteine levels did not change significantly } \\
\text { between the groups }\end{array}$ & No effect \\
\hline 25 & Shidfar F et al., 2012 [214] & Berberis vulgaris Fruit Extract & $3 \mathrm{~g} / \mathrm{d}$ & 3 months & Diabetic patients & $\begin{array}{l}\text { Berberine did not significantly alter mean serum } \\
\text { homocysteine concentration }\end{array}$ & No effect \\
\hline
\end{tabular}


Table 1. Cont.

\begin{tabular}{|c|c|c|c|c|c|c|c|}
\hline Number & Author, Year & Agent & Dose per Day & Treatment Duration & Subjects & Main Outcome(s) & $\begin{array}{l}\text { Final Effects of Nutraceuticals on } \\
\text { Homocysteine Level }\end{array}$ \\
\hline 26 & Campbell MS et al., 2019 [227] & Curcumin & $500 \mathrm{mg}$ & 12 weeks & Obese men & $\begin{array}{l}\text { Homocysteine was significantly reduced in the } \\
\text { curcumin group }\end{array}$ & $\downarrow$ \\
\hline 27 & Madaric A et al., 2013 [229] & Curcumin & $100 \mathrm{~g}$ of biscuits per day with $1.3 \mathrm{~g}$ curcuma & 2 months & Healthy men & Curcumin significantly decreased homocysteine level & $\downarrow$ \\
\hline 28 & Schroecksnadel K et al., 2005 [240] & Resveratrol & $1-100 \mu g$ & $72 \mathrm{~h}$ & Healthy voluntary blood donors & $\begin{array}{c}\text { Pretreatment of unstimulated cells with } 10-100 \mathrm{mM} \\
\text { resveratrol only slightly decreased homocysteine } \\
\text { production in the resting cells }\end{array}$ & $\downarrow$ \\
\hline 29 & Wood RJ et al., 2006 [244] & soluble fiber & $3 \mathrm{~g}$ soluble fiber & 12 weeks & 29 overweight men & $\begin{array}{l}\text { Homocysteine level did not significantly increase in } \\
\text { fiber group compared to the placebo group }\end{array}$ & No effect \\
\hline 30 & Sprecher DL et al, 2002 [245] & soluble fiber & $4 \mathrm{~g}$ soluble fiber & 8 weeks & 119 subjects & $\begin{array}{l}\text { Homocysteine levels significantly reduced in fiber } \\
\text { blend group compared to the placebo group }\end{array}$ & $\downarrow$ \\
\hline
\end{tabular}

$\uparrow:$ Increasing effect; $\downarrow$ : decreasing effect.

Table 2. The effect of herbal bioactive compounds on homocysteine levels based on animal studies.

\begin{tabular}{|c|c|c|c|c|c|c|c|}
\hline Number & Author, Year & Agent & Dose per Day & Treatment Duration & Animals & Main Outcome(s) & $\begin{array}{l}\text { Final Effects of Nutraceutical. } \\
\text { on Homocysteine Level }\end{array}$ \\
\hline 1 & San Cheang et al., 2015 [84] & Black Tea extract & $15 \mathrm{mg} / \mathrm{kg} / \mathrm{day}$ & 2 weeks & Rats & Black tea extract significantly reduced plasma homocysteine levels & $\downarrow$ \\
\hline 2 & El-Missiry MA et al, 2018 [101] & Green tea & 2.5 or $5 \mathrm{mg} / \mathrm{kg}$ body weight EGCG & 3 days & Adult male Wister rats & EGCG at a dose of 2.5 and $5 \mathrm{mg} / \mathrm{kg}$ significantly decreased plasma homocysteine & $\downarrow$ \\
\hline 3 & Amin KA et al., 2009 [108] & Cinnamon extract & $20 \mathrm{mg} / \mathrm{day} / \mathrm{rat}$ & $5-8$ weeks & Male rats & Cinnamon extract reduced homocysteine levels & $\downarrow$ \\
\hline 5 & $\operatorname{Kim} J \mathrm{H}, 2019$ [136] & ginsenoside & $50 \mathrm{mg} / \mathrm{kg}$ every $12 \mathrm{~h}$ & 60 days & 40 wistar male rats & Met reduced plasma Homocysteine level, whereas GTS did not affect basal plasma levels & $\begin{array}{l}\text { GTS alone: } \\
\text { No effect } \\
\text { Met: } \\
\downarrow\end{array}$ \\
\hline 6 & Illkhanizadeh B et al, 2016 [154] & ginger & $50 \mathrm{mg} / \mathrm{kg}$ body weight daily & 6 weeks & 24 male Wistar rats & $\begin{array}{c}\text { Significant decrease in homocystein level was found in the ginger extract-treated } \\
\text { diabetic group }\end{array}$ & $\downarrow$ \\
\hline 8 & Snelson M et al., 2017 [171] & Soy & $55 \%$ total energy & 12 weeks & 30 female wild-type mice & homocysteine level was the same in soy and control group & No effect \\
\hline 9 & Adam SK et al., 2008 [172] & Soy & $\begin{array}{c}\text { Fresh soy oil } \\
\text { One-heated soy oil } \\
\text { Five-time-heated soy oil }\end{array}$ & 4 months & 24 adult female Sprague Dawley rats & fresh soy oil significantly reduced homocysteine level compared to the other groups & $\downarrow$ \\
\hline 10 & Chang X-x et al., 2012 [213] & Berberine & $200 \mathrm{mg} / \mathrm{kg} /$ day & 24 weeks & Healthy male rats & $\begin{array}{l}\text { Serum homocysteine level was significantly decreased after berberine consumption in rats } \\
\text { fed with a high-fat diet }\end{array}$ & $\downarrow$ \\
\hline 11 & Varatharajalu R et al., 2016 [228] & Curcumin & $150 \mathrm{mg} / \mathrm{kg}$ body weight/day & 8 weeks & Female Wistar-Furth rats & Curcumin significantly increased homocysteine thiolactonase activity & $\downarrow$ \\
\hline 12 & Mansouri Z et al, 2012 [230] & Curcumin & $50 \mathrm{mg} / \mathrm{kg}$ & 10 days & Adult male Wister rats & Investigated the neuroprotective effects of curcumin against homocysteine neurotoxicity & $\downarrow$ \\
\hline 13 & Jelodar G et al., 2019 [231] & Curcumin & $48 \mathrm{mg} / \mathrm{kg}$ & 4 weeks & female Sprague-Dawley rats & no significant difference was observed between all groups & No effect \\
\hline 14 & Koz ST et al.2012 [237] & Resveratrol & $20 \mathrm{mg} / \mathrm{kg} /$ day & 30 days & Rats & Resveratrol significantly reduced plasma Homocysteine levels & $\downarrow$ \\
\hline 16 & Yilmaz Ö et al, 2007 [239] & Resveratrol & $33 \mathrm{mg} / \mathrm{kg}$ four times per week & 5 weeks & Old female rats & Resveratrol significantly decreased homocysteine levels & $\downarrow$ \\
\hline
\end{tabular}


Author Contributions: Conceptualization, M.A.A., M.B. and A.S.; writing-original draft preparation, M.A.A. and M.B.; writing-review and editing, A.S., A.T. and G.A. All authors have read and agreed to the published version of the manuscript.

Funding: This research received no external funding.

Data Availability Statement: There is no raw data associated with this review article.

Conflicts of Interest: No author of us has to disclosure any conflict of interest.

\section{References}

1. Kavey, R.-E.W.; Daniels, S.R.; Lauer, R.M.; Atkins, D.L.; Hayman, L.L.; Taubert, K. American Heart Association Guidelines for Primary Prevention of Atherosclerotic Cardiovascular Disease Beginning in Childhood. Circulation 2003, 107, 1562-1566. [CrossRef] [PubMed]

2. Williams, C.L.; Hayman, L.L.; Daniels, S.R.; Robinson, T.N.; Steinberger, J.; Paridon, S.; Bazzarre, T.J.C. Cardiovascular health in childhood: A statement for health professionals from the Committee on Atherosclerosis, Hypertension, and Obesity in the Young (AHOY) of the Council on Cardiovascular Disease in the Young, American Heart Association. Circulation 2002, 106, 143-160. [CrossRef] [PubMed]

3. Murray, C.J.; Lopez, A.D.; W.H.O. The Global Burden of Disease: A Comprehensive Assessment of Mortality and Disability from Diseases, Injuries, and Risk Factors in 1990 and Projected to 2020: Summary; World Health Organization: Geneva, Switzerland, 1996.

4. Abubakar, I.; Tillmann, T.; Banerjee, A.J.L. Global, regional, and national age-sex specific all-cause and cause-specific mortality for 240 causes of death, 1990-2013: A systematic analysis for the Global Burden of Disease Study 2013. Lancet 2015, 385, 117-171.

5. Yusuf, S.; Wood, D.; Ralston, J.; Reddy, K.S.J.T.L. The World Heart Federation's vision for worldwide cardiovascular disease prevention. Lancet 2015, 386, 399-402. [CrossRef]

6. $\quad$ Levenson, J.W.; Ms, P.J.S.; Gaziano, J.M. Reducing the Global Burden of Cardiovascular Disease: The Role of Risk Factors. Prev. Cardiol. 2002, 5, 188-199. [CrossRef]

7. Okwuosa, I.S.; Lewsey, S.C.; Adesiyun, T.; Blumenthal, R.S.; Yancy, C.W. Worldwide disparities in cardiovascular disease: Challenges and solutions. Int. J. Cardiol. 2016, 202, 433-440. [CrossRef]

8. W.H.O.; World Economic Forum. From Burden to "Best Buys": Reducing the Economic Impact of Non-Communicable Diseases in Low-and Middle-Income Countries; World Health Organization: Geneva, Switzerland; World Economic Forum: Cologny, Switzerland, 2011.

9. G.H.S.I. Shifting Paradigm: How BRICS are Reshaping Global Health and Development; Global Health Strategies Initiatives: New York, NY, USA, 2012.

10. Benjamin, E.J.; Virani, S.S.; Callaway, C.W.; Chamberlain, A.M.; Chang, A.R.; Cheng, S.; Chiuve, S.E.; Cushman, M.; Delling, F.N.; Deo, R.J.C. Heart disease and stroke statistics—2018 update: A report from the American Heart Association. Circulation 2018, 137, e67-e492. [CrossRef]

11. Laslett, L.J.; Alagona, P.; Clark, B.A.; Drozda, J.P.; Saldivar, F.; Wilson, S.R.; Poe, C.; Hart, M. The worldwide environment of cardiovascular disease: Prevalence, diagnosis, therapy, and policy issues: A report from the American College of Cardiology. J. Am. Coll. Cardiol. 2012, 60, S1-S49. [CrossRef]

12. Finkelstein, J.D.; Martin, J.J. Homocysteine. Int. J. Biochem. Cell Biol. 2000, 32, 385-389. [CrossRef]

13. Mudd, S.; Ebert, M.H.; Scriver, C.R. Labile methyl group balances in the human: The role of sarcosine. Metabolism 1980, 29 , 707-720. [CrossRef]

14. Mudd, S.; Poole, J.R. Labile methyl balances for normal humans on various dietary regimens. Metabolism 1975, 24, 721-735. [CrossRef]

15. Finkelstein, J.D.J. Methionine metabolism in mammals. J. Nutr. Biochem. 1990, 1, 228-237. [CrossRef]

16. McKeever, M.P.; Weir, D.G.; Molloy, A.; Scott, J.M. Betaine-homocysteine methyltransferase: Organ distribution in man, pig and rat and subcellular distribution in the rat. Clin. Sci. 1991, 81, 551-556. [CrossRef] [PubMed]

17. Selhub, J. Homocysteine metabolism. Annu. Rev. Nutr. 1999, 19, 217-246. [CrossRef] [PubMed]

18. Christensen, B.; Refsum, H.; Vintermyr, O.; Ueland, P.M. Homocysteine export from cells cultured in the presence of physiological or superfluous levels of methionine: Methionine loading of non-transformed, transformed, proliferating, and quiescent cells in culture. J. Cell. Physiol. 1991, 146, 52-62. [CrossRef] [PubMed]

19. Ueland, P.M.; Refsum, H.; Male, R.; Lillehaug, J.R. Disposition of endogenous homocysteine by mouse fibroblast C3H/10T1/2 CI 8 and the chemically transformed C3H/10T1/2 MCA CI 16 cells following methotrexate exposure. J. Natl. Cancer Inst. 1986, 77, 283-289. [PubMed]

20. Refsum, H.; Ueland, P.M. Recent data are not in conflict with homocysteine as a cardiovascular risk factor. Curr. Opin. Lipidol. 1998, 9, 533-539. [CrossRef] [PubMed]

21. Kang, S.-S.; Wong, P.W.; Malinow, M.R. Hyperhomocyst (e) inemia as a risk factor for occlusive vascular disease. Annu. Rev. Nutr. 1992, 12, 279-298. [CrossRef]

22. Maron, B.A.; Loscalzo, J. The treatment of hyperhomocysteinemia. Annu. Rev. Med. 2009, 60, 39-54. [CrossRef]

23. Martí-Carvajal, A.J.; Solà, I.; Lathyris, D.; Dayer, M. Homocysteine-lowering interventions for preventing cardiovascular events. Cochrane Database Syst. Rev. 2017, 8, CD006612. [CrossRef] 
24. Lindqvist, M.; Hellström, A.; Henriksson, A.E. Abdominal aortic aneurysm and the association with serum levels of Homocysteine, vitamins B6, B12 and Folate. Am. J. Cardiovasc. Dis. 2012, 2, 318. [PubMed]

25. Warsi, A.; Davies, B.; Morris-Stiff, G.; Hullin, D.; Lewis, M. Abdominal Aortic Aneurysm and its Correlation to Plasma Homocysteine, and Vitamins. Eur. J. Vasc. Endovasc. Surg. 2004, 27, 75-79. [CrossRef]

26. Wald, D.S.; Law, M.; Morris, J. Homocysteine and cardiovascular disease: Evidence on causality from a meta-analysis. BMJ 2002, 325, 1202-1206. [CrossRef]

27. Humphrey, L.L.; Fu, R.; Rogers, K.; Freeman, M.; Helfand, M. Homocysteine Level and Coronary Heart Disease Incidence: A Systematic Review and Meta-analysis. Mayo Clin. Proc. 2008, 83, 1203-1212. [CrossRef]

28. Homocysteine Studies Collaboration. Homocysteine and risk of ischemic heart disease and stroke. JAMA 2002, 288, 2015-2022. [CrossRef]

29. Maciel, F.R.; Punaro, G.R.; Rodrigues, A.M.; Bogsan, C.S.; Rogero, M.M.; Oliveira, M.N.; Mouro, M.G.; Higa, E.M. Immunomodulation and nitric oxide restoration by a probiotic and its activity in gut and peritoneal macrophages in diabetic rats. Clin. Nutr. 2016, 35, 1066-1072. [CrossRef]

30. Klerk, M.; Verhoef, P.; Clarke, R.; Blom, H.J.; Kok, F.J.; Schouten, E.G. MTHFR 677C $\rightarrow$ T polymorphism and risk of coronary heart disease: A meta-analysis. JAMA 2002, 288, 2023-2031. [CrossRef]

31. Azad, A.K.; Huang, P.; Liu, G.; Ren, W.; Teklebrh, T.; Yan, W.; Zhou, X.; Yin, Y. Hyperhomocysteinemia and cardiovascular disease in animal model. Amino Acids 2018, 50, 3-9. [CrossRef]

32. Balint, B.; Jepchumba, V.K.; Guéant, J.-L.; Guéant-Rodriguez, R.-M. Mechanisms of homocysteine-induced damage to the endothelial, medial and adventitial layers of the arterial wall. Biochimie 2020, 173, 100-106. [CrossRef]

33. Dayal, S.; Bottiglieri, T.; Arning, E.; Maeda, N.; Malinow, M.R.; Sigmund, C.D.; Heistad, D.D.; Faraci, F.M.; Lentz, S.R. Endothelial Dysfunction and Elevation of S-Adenosylhomocysteine in Cystathionine $\beta$-Synthase-Deficient Mice. Circ. Res. 2001, 88, 1203-1209. [CrossRef]

34. Eberhardt, R.T.; Forgione, M.A.; Cap, A.; Leopold, J.A.; Rudd, M.A.; Trolliet, M.; Heydrick, S.; Stark, R.; Klings, E.S.; Moldovan, N.I.; et al. Endothelial dysfunction in a murine model of mild hyperhomocyst(e)inemia. J. Clin. Investig. 2000, 106, 483-491. [CrossRef] [PubMed]

35. Jiang, X.; Yang, F.; Tan, H.; Liao, D.; Bryan, R.M., Jr.; Randhawa, J.K.; Rumbaut, R.E.; Durante, W.; Schafer, A.I.; Yang, X.J. Hyperhomocystinemia impairs endothelial function and eNOS activity via PKC activation. Arterioscler. Thromb. Vasc. Biol. 2005, 25, 2515-2521. [CrossRef] [PubMed]

36. Lentz, S.R.; Erger, R.A.; Dayal, S.; Maeda, N.; Malinow, M.R.; Heistad, D.D.; Faraci, F.M. Folate dependence of hyperhomocysteinemia and vascular dysfunction in cystathionine $\beta$-synthase-deficient mice. Am. J. Physiol. Circ. Physiol. 2000, 279, H970-H975. [CrossRef] [PubMed]

37. Li, L.; Hasegawa, H.; Inaba, N.; Yoshioka, W.; Chang, D.; Liu, J.; Ichida, K. Diet-induced hyperhomocysteinemia impairs vasodilation in 5/6-nephrectomized rats. Amino Acids 2018, 50, 1485-1494. [CrossRef]

38. Liu, L.-H.; Guo, Z.; Feng, M.; Wu, Z.-Z.; He, Z.-M.; Xiong, Y. Protection of DDAH2 Overexpression Against HomocysteineInduced Impairments of DDAH/ADMA/NOS/NO Pathway in Endothelial Cells. Cell. Physiol. Biochem. 2012, 30, $1413-1422$. [CrossRef]

39. Szabo, C.J. Hydrogen sulfide, an enhancer of vascular nitric oxide signaling: Mechanisms and implications. Am. J. Physiol. Cell Physiol. 2017, 312, C3-C15. [CrossRef]

40. Han, S.; Wu, H.; Li, W.; Gao, P. Protective effects of genistein in homocysteine-induced endothelial cell inflammatory injury. Mol. Cell. Biochem. 2015, 403, 43-49. [CrossRef]

41. Kamat, P.; Kalani, A.; Givvimani, S.; Sathnur, P.; Tyagi, S.; Tyagi, N. Hydrogen sulfide attenuates neurodegeneration and neurovascular dysfunction induced by intracerebral-administered homocysteine in mice. Neuroscience 2013, 252, 302-319. [CrossRef]

42. Li, J.; Luo, M.; Xie, N.; Wang, J.; Chen, L. Curcumin protects endothelial cells against homocysteine induced injury through inhibiting inflammation. Am. J. Transl. Res. 2016, 8, 4598-4604.

43. Wu, X.; Zhang, L.; Miao, Y.; Yang, J.; Wang, X.; Wang, C.-C.; Feng, J.; Wang, L. Homocysteine causes vascular endothelial dysfunction by disrupting endoplasmic reticulum redox homeostasis. Redox Biol. 2019, 20, 46-59. [CrossRef]

44. Zulli, A.; Widdop, R.E.; Hare, D.L.; Buxton, B.F.; Black, M.J. High Methionine and Cholesterol Diet Abolishes Endothelial Relaxation. Arter. Thromb. Vasc. Biol. 2003, 23, 1358-1363. [CrossRef]

45. Sipkens, J.A.; Hahn, N.; Brand, C.S.V.D.; Meischl, C.; Cillessen, S.A.G.M.; Smith, D.E.C.; Juffermans, L.J.M.; Musters, R.J.P.; Roos, D.; Jakobs, C.; et al. Homocysteine-Induced Apoptosis in Endothelial Cells Coincides with Nuclear NOX2 and Peri-nuclear NOX4 Activity. Cell Biophys. 2011, 67, 341-352. [CrossRef]

46. Gurda, D.; Handschuh, L.; Kotkowiak, W.; Jakubowski, H. Homocysteine thiolactone and N-homocysteinylated protein induce pro-atherogenic changes in gene expression in human vascular endothelial cells. Amino Acids 2015, 47, 1319-1339. [CrossRef]

47. Buemi, M.; Marino, D.; Di Pasquale, G.; Floccari, F.; Ruello, A.; Aloisi, C.; Corica, F.; Senatore, M.; Romeo, A.; Frisina, N. Effects of Homocysteine on Proliferation, Necrosis, and Apoptosis of Vascular Smooth Muscle Cells in Culture and Influence of Folic Acid. Thromb. Res. 2001, 104, 207-213. [CrossRef] 
48. Tsai, J.C.; Wang, H.; Perrella, M.A.; Yoshizumi, M.; Sibinga, N.E.; Tan, L.C.; Haber, E.; Chang, T.H.; Schlegel, R.; Lee, M.E. Induction of cyclin A gene expression by homocysteine in vascular smooth muscle cells. J. Clin. Investig. 1996, 97, 146-153. [CrossRef]

49. Küskü-Kiraz, Z.; Genc, S.; Bekpınar, S.; Ünlücerci, Y.; Çevik, A.; Olgaç, V.; Gürdöl, F.; Uysal, M. Effects of betaine supplementation on nitric oxide metabolism, atherosclerotic parameters, and fatty liver in guinea pigs fed a high cholesterol plus methionine diet. Nutrients 2018, 45, 41-48. [CrossRef]

50. Majesky, M.W. Developmental basis of vascular smooth muscle diversity. Arterioscler. Thromb. Vasc. Biol. 2007, 27, 1248-1258. [CrossRef]

51. Hofmann, M.A.; Lalla, E.; Lu, Y.; Gleason, M.R.; Wolf, B.M.; Tanji, N.; Ferran, L.J.; Kohl, B.; Rao, V.; Kisiel, W.; et al. Hyperhomocysteinemia enhances vascular inflammation and accelerates atherosclerosis in a murine model. J. Clin. Investig. 2001, 107, 675-683. [CrossRef]

52. Liu, X.; Luo, F.; Li, J.; Wu, W.; Li, L.; Chen, H. Homocysteine induces connective tissue growth factor expression in vascular smooth muscle cells. J. Thromb. Haemost. 2007, 6, 184-192. [CrossRef]

53. Ovechkin, A.V.; Tyagi, N.; Sen, U.; Lominadze, D.; Steed, M.M.; Moshal, K.S.; Tyagi, S.C. 3-Deazaadenosine mitigates arterial remodeling and hypertension in hyperhomocysteinemic mice. Am. J. Physiol. Cell. Mol. Physiol. 2006, 291, L905-L911. [CrossRef]

54. Wilson, K.; Lindholt, J.; Hoskins, P.; Heickendorff, L.; Vammen, S.; Bradbury, A. The Relationship Between Abdominal Aortic Aneurysm Distensibility and Serum Markers of Elastin and Collagen Metabolism. Eur. J. Vasc. Endovasc. Surg. 2001, 21, 175-178. [CrossRef] [PubMed]

55. Leon, A.S.; Bronas, U.G. Dyslipidemia and risk of coronary heart disease: Role of lifestyle approaches for its management. Am. J. Lifestyle Med. 2009, 3, 257-273. [CrossRef]

56. Bagherniya, M.; Nobili, V.; Blesso, C.N.; Sahebkar, A. Medicinal plants and bioactive natural compounds in the treatment of non-alcoholic fatty liver disease: A clinical review. Pharmacol. Res. 2018, 130, 213-240. [CrossRef] [PubMed]

57. Gurib-Fakim, A. Medicinal plants: Traditions of yesterday and drugs of tomorrow. Mol. Asp. Med. 2006, 27, 1-93. [CrossRef]

58. Moss, J.W.; Ramji, D.P. Nutraceutical therapies for atherosclerosis. Nat. Rev. Cardiol. 2016, 13, 513-532. [CrossRef]

59. Sosnowska, B.; Penson, P.; Banach, M. The role of nutraceuticals in the prevention of cardiovascular disease. Cardiovasc. Diagn. Ther. 2017, 67, S21-S31. [CrossRef]

60. DeFelice, S.L. The nutraceutical revolution: Its impact on food industry R\&D. Trends Food Sci. Technol. 1995, 6, 59-61.

61. Santini, A.; Novellino, E. Nutraceuticals: Beyond the diet before the drugs. Curr. Bioact. Compd. 2014, 10, 1-12. [CrossRef]

62. Santini, A.; Novellino, E. Nutraceuticals in hypercholesterolaemia: An overview. Br. J. Pharmacol. 2017, 174, 1450-1463. [CrossRef]

63. Alissa, E.M.; Ferns, G.A. Functional Foods and Nutraceuticals in the Primary Prevention of Cardiovascular Diseases. J. Nutr. Metab. 2012, 2012, 1-16. [CrossRef]

64. Ramaa, C.S.; Shirode, A.R.; Mundada, A.S.; Kadam, V.J. Nutraceuticals-An Emerging Era in the Treatment and Prevention of Cardiovascular Diseases. Curr. Pharm. Biotechnol. 2006, 7, 15-23. [CrossRef]

65. Zuchi, C.; Ambrosio, G.; Lüscher, T.F.; Landmesser, U. Nutraceuticals in Cardiovascular Prevention: Lessons from Studies on Endothelial Function. Cardiovasc. Ther. 2010, 28, 187-201. [CrossRef]

66. Badimon, L.; Vilahur, G.; Padro, T. Nutraceuticals and Atherosclerosis: Human Trials. Cardiovasc. Ther. 2010, 28, 202-215. [CrossRef]

67. McCarty, M.F. Nutraceutical resources for diabetes prevention-An update. Med. Hypotheses 2005, 64, 151-158. [CrossRef]

68. Davì, G.; Santilli, F.; Patrono, C. Nutraceuticals in Diabetes and Metabolic Syndrome. Cardiovasc. Ther. 2010, 28, 216-226. [CrossRef]

69. Bahadoran, Z.; Mirmiran, P.; Azizi, F. Dietary polyphenols as potential nutraceuticals in management of diabetes: A review. J. Diabetes Metab. Disord. 2013, 12, 43. [CrossRef] [PubMed]

70. Houston, M. The role of nutrition and nutraceutical supplements in the treatment of hypertension. World J. Cardiol. 2014, 6, 38-66. [CrossRef]

71. Houston, M.C. Nutraceuticals, Vitamins, Antioxidants, and Minerals in the Prevention and Treatment of Hypertension. Prog. Cardiovasc. Dis. 2005, 47, 396-449. [CrossRef]

72. Houston, M.C. Nutrition and nutraceutical supplements in the treatment of hypertension. Expert Rev. Cardiovasc. Ther. 2010, 8, 821-833. [CrossRef]

73. Mahdavi, A.; Bagherniya, M.; Fakheran, O.; Reiner, Ž.; Xu, S.; Sahebkar, A. Medicinal plants and bioactive natural compounds as inhibitors of HMG-CoA reductase: A literature review. BioFactors 2020, 46, 906-926. [CrossRef]

74. Talebi, S.; Bagherniya, M.; Atkin, S.L.; Askari, G.; Orafai, H.M.; Sahebkar, A. The beneficial effects of nutraceuticals and natural products on small dense LDL levels, LDL particle number and LDL particle size: A clinical review. Lipids Health Dis. 2020, 19, 1-21. [CrossRef] [PubMed]

75. Izzo, R.; de Simone, G.; Giudice, R.; Chinali, M.; Trimarco, V.; De Luca, N.; Trimarco, B. Effects of nutraceuticals on prevalence of metabolic syndrome and on calculated Framingham Risk Score in individuals with dyslipidemia. J. Hypertens. 2010, 28, 1482-1487. [CrossRef]

76. Houston, M. The Role of Nutraceutical Supplements in the Treatment of Dyslipidemia. J. Clin. Hypertens. 2012, 14, 121-132. [CrossRef] 
77. Sirtori, C.R.; Galli, C.; Anderson, J.W.; Arnoldi, A. Nutritional and nutraceutical approaches to dyslipidemia and atherosclerosis prevention: Focus on dietary proteins. Atherosclerosis 2009, 203, 8-17. [CrossRef] [PubMed]

78. Mannarino, M.R.; Ministrini, S.; Pirro, M. Nutraceuticals for the treatment of hypercholesterolemia. Eur. J. Intern. Med. 2014, 25, 592-599. [CrossRef] [PubMed]

79. Scicchitano, P.; Cameli, M.; Maiello, M.; Modesti, P.A.; Muiesan, M.L.; Novo, S.; Palmiero, P.; Saba, P.S.; Pedrinelli, R.; Ciccone, M.M. Nutraceuticals and dyslipidaemia: Beyond the common therapeutics. J. Funct. Foods 2014, 6, 11-32. [CrossRef]

80. Arab, L.; Liu, W.; Elashoff, D. Green and black tea consumption and risk of stroke: A meta-analysis. Stroke 2009, 40, 1786-1792. [CrossRef] [PubMed]

81. Bahorun, T.; Luximon-Ramma, A.; Gunness, T.K.; Sookar, D.; Bhoyroo, S.; Jugessur, R.; Reebye, D.; Googoolye, K.; Crozier, A.; Aruoma, O.I. Black tea reduces uric acid and C-reactive protein levels in humans susceptible to cardiovascular diseases. Toxicology 2010, 278, 68-74. [CrossRef]

82. Vasisht, K. Study to Promote the Industrial Exploitation of Green Tea Polyphenols in India; UNIDO: Vienna, Austria, 2003.

83. Hayat, K.; Iqbal, H.; Malik, U.; Bilal, U.; Mushtaq, S. Tea and Its Consumption: Benefits and Risks. Crit. Rev. Food Sci. Nutr. 2015, 55, 939-954. [CrossRef]

84. Cheang, W.S.; Ngai, C.Y.; Tam, Y.Y.; Tian, X.Y.; Wong, W.T.; Zhang, Y.; Lau, C.W.; Chen, Z.Y.; Bian, Z.-X.; Huang, Y.; et al. Black tea protects against hypertension-associated endothelial dysfunction through alleviation of endoplasmic reticulum stress. Sci. Rep. 2015, 5, 10340. [CrossRef]

85. Hodgson, J.M.; Puddey, I.B.; Van Bockxmeer, F.M.; Burke, V. Acute effects of tea on fasting and non-fasting plasma total homocysteine concentrations in human subjects. Br. J. Nutr. 2007, 97, 842-846. [CrossRef]

86. Hodgson, J.M.; Burke, V.; Beilin, L.J.; Croft, K.D.; Puddey, I.B. Can black tea influence plasma total homocysteine concentrations? Am. J. Clin. Nutr. 2003, 77, 907-911. [CrossRef]

87. Olthof, M.R.; Hollman, P.C.; Zock, P.L.; Katan, M.B. Consumption of high doses of chlorogenic acid, present in coffee, or of black tea increases plasma total homocysteine concentrations in humans. Am. J. Clin. Nutr. 2001, 73, 532-538. [CrossRef]

88. Urgert, R.; Van Vliet, T.; Zock, P.L.; Katan, M.B. Heavy coffee consumption and plasma homocysteine: A randomized controlled trial in healthy volunteers. Am. J. Clin. Nutr. 2000, 72, 1107-1110. [CrossRef]

89. Verhoef, P.; Pasman, W.J.; Van Vliet, T.; Urgert, R.; Katan, M.B. Contribution of caffeine to the homocysteine-raising effect of coffee: A randomized controlled trial in humans. Am. J. Clin. Nutr. 2002, 76, 1244-1248. [CrossRef]

90. Hartley, L.; Flowers, N.; Holmes, J.; Clarke, A.; Stranges, S.; Hooper, L.; Rees, K. Green and black tea for the primary prevention of cardiovascular disease. Cochrane Database Syst. Rev. 2013. [CrossRef]

91. Mineharu, Y.; Koizumi, A.; Wada, Y.; Iso, H.; Watanabe, Y.; Date, C.; Yamamoto, A.; Kikuchi, S.; Inaba, Y.; Toyoshima, H.; et al. Coffee, green tea, black tea and oolong tea consumption and risk of mortality from cardiovascular disease in Japanese men and women. J. Epidemiol. Community Health 2009, 65, 230-240. [CrossRef]

92. Tang, J.; Zheng, J.-S.; Fang, L.; Jin, Y.; Cai, W.; Li, D. Tea consumption and mortality of all cancers, CVD and all causes: A meta-analysis of eighteen prospective cohort studies. Br. J. Nutr. 2015, 114, 673-683. [CrossRef]

93. Cabrera, C.; Artacho, R.; Giménez, R. Beneficial effects of green tea-A review. J. Am. Coll. Nutr. 2006, 25, 79-99. [CrossRef]

94. Goszcz, K.; Duthie, G.G.; Stewart, D.; Leslie, S.J.; Megson, I.L. Bioactive polyphenols and cardiovascular disease: Chemical antagonists, pharmacological agents or xenobiotics that drive an adaptive response? Br. J. Pharmacol. 2017, 174, 1209-1225. [CrossRef]

95. Šilarová, P.; Česlová, L.; Meloun, M. Fast gradient HPLC/MS separation of phenolics in green tea to monitor their degradation. Food Chem. 2017, 237, 471-480. [CrossRef] [PubMed]

96. Assi, M. The Impact of Physical Activity and Antioxidants on Tumor-Skeletal Muscle Crosstalk during Cancer: Deciphering Signaling Pathways Involved in Tumor Growth and Muscle Wasting. Ph.D. Thesis, University Rennes 2, Rennes, France, 2016.

97. Lee, S.-R.; Suh, S.-I.; Kim, S.-P. Protective effects of the green tea polyphenol (-)-epigallocatechin gallate against hippocampal neuronal damage after transient global ischemia in gerbils. Neurosci. Lett. 2000, 287, 191-194. [CrossRef]

98. Ortiz-López, L.; Márquez-Valadez, B.; Gómez-Sánchez, A.; Silva-Lucero, M.; Torres-Pérez, M.; Téllez-Ballesteros, R.; Ichwan, M.; Meraz-Ríos, M.; Kempermann, G.; Ramírez-Rodríguez, G. Green tea compound epigallo-catechin-3-gallate (EGCG) increases neuronal survival in adult hippocampal neurogenesis in vivo and in vitro. Neuroscience 2016, 322, 208-220. [CrossRef] [PubMed]

99. Bagherniya, M.; Khedmatgozar, H.; Fakheran, O.; Xu, S.; Johnston, T.P.; Sahebkar, A. Medicinal plants and bioactive natural products as inhibitors of NLRP3 inflammasome. Phytother. Res. 2021. [CrossRef]

100. Wang, L.; Tian, X. Epigallocatechin-3-Gallate Protects against Homocysteine-Induced Brain Damage in Rats. Planta Med. 2017, 84, 34-41. [CrossRef]

101. El-Missiry, M.A.; Othman, A.I.; El-Sawy, M.R.; Lebede, M.F. Neuroprotective effect of epigallocatechin-3-gallate (EGCG) on radiation-induced damage and apoptosis in the rat hippocampus. Int. J. Radiat. Biol. 2018, 94, 798-808. [CrossRef]

102. Ranasinghe, P.; Pigera, S.; Premakumara, G.A.S.; Galappaththy, P.; Constantine, G.R.; Katulanda, P. Medicinal properties of 'true' cinnamon (Cinnamomum zeylanicum): A systematic review. BMC Complement. Altern. Med. 2013, 13, 275. [CrossRef]

103. Bandara, T.; Uluwaduge, I.; Jansz, E.R. Bioactivity of cinnamon with special emphasis on diabetes mellitus: A review. Int. J. Food Sci. Nutr. 2011, 63, 380-386. [CrossRef]

104. Deng, R. A review of the hypoglycemic effects of five commonly used herbal food supplements. Recent Pat. Foodnutrition Agric. 2012, 4, 50-60. 
105. Mousavi, S.M.; Rahmani, J.; Kord-Varkaneh, H.; Sheikhi, A.; Larijani, B.; Esmaillzadeh, A. Cinnamon supplementation positively affects obesity: A systematic review and dose-response meta-analysis of randomized controlled trials. Clin. Nutr. 2020, 39, 123-133. [CrossRef]

106. Mahdavi, A.; Bagherniya, M.; Mirenayat, M.S.; Atkin, S.L.; Sahebkar, A. Medicinal Plants and Phytochemicals Regulating Insulin Resistance and Glucose Homeostasis in Type 2 Diabetic Patients: A Clinical Review. Adv. Exp. Med. Biol. 2021, 1308, 161-183. [CrossRef]

107. Barceloux, D.G. Cinnamon (Cinnamomum Species). Dis. Mon. 2009, 55, 327-335. [CrossRef]

108. Amin, K.A.; El-Twab, T.M.A. Oxidative markers, nitric oxide and homocysteine alteration in hypercholesterolimic rats: Role of atorvastatine and cinnamon. Int. J. Clin. Exp. Med. 2009, 2, 254-265.

109. Waterhouse, A.L. Determination of total phenolics. Curr. Protoc. Food Anal. Chem. 2002, 6. [CrossRef]

110. Buchert, J.; Koponen, J.M.; Suutarinen, M.; Mustranta, A.; Lille, M.; Törrönen, R.; Poutanen, K. Effect of enzyme-aided pressing on anthocyanin yield and profiles in bilberry and blackcurrant juices. J. Sci. Food Agric. 2005, 85, 2548-2556. [CrossRef]

111. Valenti, L.; Riso, P.; Mazzocchi, A.; Porrini, M.; Fargion, S.; Agostoni, C. Dietary Anthocyanins as Nutritional Therapy for Nonalcoholic Fatty Liver Disease. Oxidative Med. Cell. Longev. 2013, 2013, 1-8. [CrossRef]

112. Lee, J.; Durst, R.W.; Wrolstad, R.E. Determination of Total Monomeric Anthocyanin Pigment Content of Fruit Juices, Beverages, Natural Colorants, and Wines by the pH Differential Method: Collaborative Study. J. AOAC Int. 2005, 88, 1269-1278. [CrossRef]

113. Chandrasekhar, J.; Madhusudhan, M.; Raghavarao, K. Extraction of anthocyanins from red cabbage and purification using adsorption. Food Bioprod. Process. 2012, 90, 615-623. [CrossRef]

114. Ho, S.-C.; Hwang, L.S.; Shen, Y.-J.; Lin, C.-C. Suppressive Effect of a Proanthocyanidin-rich Extract from Longan (Dimocarpus longan Lour.) Flowers on Nitric Oxide Production in LPS-Stimulated Macrophage Cells. J. Agric. Food Chem. 2007, 55, 10664-10670. [CrossRef]

115. Duthie, S.J.; Jenkinson, A.M.E.; Crozier, A.; Mullen, W.; Pirie, L.; Kyle, J.; Yap, L.S.; Christen, P.; Duthie, G.G. The effects of cranberry juice consumption on antioxidant status and biomarkers relating to heart disease and cancer in healthy human volunteers. Eur. J. Nutr. 2006, 45, 113-122. [CrossRef]

116. Mikaili, P.; Maadirad, S.; Moloudizargari, M.; Aghajanshakeri, S.; Sarahroodi, S. Therapeutic Uses and Pharmacological Properties of Garlic, Shallot, and Their Biologically Active Compounds. Iran J. Basic Med. Sci. 2013, 16, 1031-1048.

117. Ankri, S.; Mirelman, D. Antimicrobial properties of allicin from garlic. Microbes Infect. 1999, 1, 125-129. [CrossRef]

118. Josling, P. Preventing the common cold with a garlic supplement: A double-blind, placebo-controlled survey. Adv. Ther. 2001, 18, 189-193. [CrossRef] [PubMed]

119. Khodavandi, A.; Alizadeh, F.; Aala, F.; Sekawi, Z.; Chong, P.P. In Vitro Investigation of Antifungal Activity of Allicin Alone and in Combination with Azoles Against Candida Species. Mycopathology 2009, 169, 287-295. [CrossRef] [PubMed]

120. Lima, C.M.B.L.; Freitas, F.I.D.S.; Morais, L.C.S.L.D.; Cavalcanti, M.G.D.S.; Silva, L.F.D.; Padilha, R.J.R.; Barbosa, C.G.S.; Santos, F.A.B.D.; Alves, L.C.; Diniz, M.D.F.F.M. Ultrastructural study on the morphological changes to male worms of Schistosoma mansoni after in vitro exposure to allicin. Revista Sociedade Brasileira Medicina Tropical 2011, 44, 327-330. [CrossRef] [PubMed]

121. Younis, F.; Mirelman, D.; Rabinkov, A.; Rosenthal, T. S-Allyl-Mercapto-Captopril: A Novel Compound in the Treatment of Cohen-Rosenthal Diabetic Hypertensive Rats. J. Clin. Hypertens. 2010, 12, 451-455. [CrossRef]

122. Krishna, A.; Yadav, A. Lead compound design for TPR/COX dual inhibition. J. Mol. Model. 2012, 18, 4397-4408. [CrossRef]

123. Park, H.S.; Kim, G.-Y.; Choi, I.-W.; Kim, N.D.; Hwang, H.J.; Choi, Y.-W.; Choi, Y.H. Inhibition of Matrix Metalloproteinase Activities and Tightening of Tight Junctions by Diallyl Disulfide in AGS Human Gastric Carcinoma Cells. J. Food Sci. 2011, 76, T105-T111. [CrossRef]

124. Tattelman, E. Health effects of garlic. Am. Fam. Physician 2005, 72, 103-106.

125. Ahmadi, N.; Nabavi, V.; Hajsadeghi, F.; Zeb, I.; Flores, F.; Ebrahimi, R.; Budoff, M. Aged garlic extract with supplement is associated with increase in brown adipose, decrease in white adipose tissue and predict lack of progression in coronary atherosclerosis. Int. J. Cardiol. 2013, 168, 2310-2314. [CrossRef]

126. Budoff, M.J.; Ahmadi, N.; Gul, K.M.; Liu, S.T.; Flores, F.R.; Tiano, J.; Takasu, J.; Miller, E.; Tsimikas, S. Aged garlic extract supplemented with B vitamins, folic acid and l-arginine retards the progression of subclinical atherosclerosis: A randomized clinical trial. Prev. Med. 2009, 49, 101-107. [CrossRef]

127. Yeh, Y.-Y.; Yeh, S.-M. Homocysteine-Lowering Action Is Another Potential Cardiovascular Protective Factor of Aged Garlic Extract. J. Nutr. 2006, 136, 745S-749S. [CrossRef]

128. Budoff, M.J.; Takasu, J.; Flores, F.R.; Niihara, Y.; Lu, B.; Lau, B.H.; Rosen, R.T.; Amagase, H. Inhibiting progression of coronary calcification using Aged Garlic Extract in patients receiving statin therapy: A preliminary study. Prev. Med. 2004, 39, 985-991. [CrossRef] [PubMed]

129. Seo, D.Y.; Lee, S.R.; Kim, H.K.; Baek, Y.H.; Kwak, Y.S.; Ko, T.H.; Kim, N.; Rhee, B.D.; Ko, K.S.; Park, B.J.; et al. Independent beneficial effects of aged garlic extract intake with regular exercise on cardiovascular risk in postmenopausal women. Nutr. Res. Pr. 2012, 6, 226-231. [CrossRef]

130. McCrindle, B.W.; Helden, E.; Conner, W.T. Garlic Extract Therapy in Children with Hypercholesterolemia. Arch. Pediatr. Adolesc. Med. 1998, 152, 1089-1094. [CrossRef]

131. Ried, K.; Travica, N.; Sali, A. The effect of aged garlic extract on blood pressure and other cardiovascular risk factors in uncontrolled hypertensives: The AGE at Heart trial. Integr. Blood Press. Control. 2016, 9, 9-21. [CrossRef] 
132. Wee, J.J.; Park, K.M.; Chung, A.-S. Biological activities of ginseng and its application to human health. Herb. Med. Biomol. Clin. Asp. 2011, 2, 157-174.

133. Park, S.E.; Park, C.; Kim, S.H.; Hossain, M.A.; Kim, M.Y.; Chung, H.Y.; Son, W.S.; Kim, G.-Y.; Choi, Y.H.; Kim, N.D. Korean red ginseng extract induces apoptosis and decreases telomerase activity in human leukemia cells. J. Ethnopharmacol. 2009, 121, 304-312. [CrossRef]

134. Vuksan, V.; Sung, M.-K.; Sievenpiper, J.L.; Stavro, P.M.; Jenkins, A.L.; Di Buono, M.; Lee, K.-S.; Leiter, L.A.; Nam, K.Y.; Arnason, J.T.; et al. Korean red ginseng (Panax ginseng) improves glucose and insulin regulation in well-controlled, type 2 diabetes: Results of a randomized, double-blind, placebo-controlled study of efficacy and safety. Nutr. Metab. Cardiovasc. Dis. 2008, 18, 46-56. [CrossRef]

135. Kim, J.-H.; Cho, S.Y.; Lee, J.-H.; Jeong, S.M.; Yoon, I.-S.; Lee, B.-H.; Lee, J.-H.; Pyo, M.K.; Lee, S.-M.; Chung, J.-M.; et al. Neuroprotective effects of ginsenoside Rg3 against homocysteine-induced excitotoxicity in rat hippocampus. Brain Res. 2007, 1136, 190-199. [CrossRef]

136. Kim, J.-H. Ginseng Total Saponin Attenuate Cardiac Hypertrophy Induced by Homocysteine in Rats. J. Ginseng Res. 2009, 33, 260-267. [CrossRef]

137. Belasco, W. Algae Burgers for a Hungry World? The Rise and Fall of Chlorella Cuisine. Technol. Cult. 1997, 38, 608. [CrossRef]

138. Komiyama, K.; Hirokawa, Y.; Mocota, T. Chlorella in cancer therapy. Chemotherapy 1986, 34, 302-307.

139. Konishi, F.; Tanaka, K.; Himeno, K.; Taniguchi, K.; Nomoto, K. Antitumor effect induced by a hot water extract of Chlorella vulgaris (CE): Resistance to meth-A tumor growth mediated by CE-induced polymorphonuclear leukocytes. Cancer Immunol. Immunother. 1985, 19, 73-78. [CrossRef]

140. Merchant, R.E.; Rice, C.D.; Young, H.F. Dietary Chlorella pyrenoidosa for patients with malignant glioma: Effects on immunocompetence, quality of life, and survival. Phytother. Res. 1990, 4, 220-231. [CrossRef]

141. Mitsuda, H.; Nishikawa, Y.; Higuchi, M.; Nakajima, K.; Kawai, F. Effect of the Breaking of Chlorella Cells on the Digestibility of Chlorella Protein. Eiyo Shokuryo 1977, 30, 93-98. [CrossRef]

142. Miyazawa, Y.; Murayama, T.; Ooya, N.; Wang, L.; Tung, Y.; Yamaguchi, N. Immunomodulation by a unicellular green algae (Chlorella pyrenoidosa) in tumor-bearing mice. J. Ethnopharmacol. 1988, 24, 135-146. [CrossRef]

143. Tanaka, K.; Koga, T.; Konishi, F.; Nakamura, M.; Mitsuyama, M.; Himeno, K.; Nomoto, K. Augmentation of host defense by a unicellular green alga, Chlorella vulgaris, to Escherichia coli infection. Infect. Immun. 1986, 53, 267-271. [CrossRef]

144. Merchant, R.E.; Phillips, T.W.; Udani, J. Nutritional Supplementation with Chlorella pyrenoidosa Lowers Serum Methylmalonic Acid in Vegans and Vegetarians with a Suspected Vitamin B12 Deficiency. J. Med. Food 2015, 18, 1357-1362. [CrossRef]

145. White, B. Ginger: An overview. Am. Fam. Physician 2007, 75, 1689-1691.

146. Borrelli, F.; Capasso, R.; Aviello, G.; Pittler, M.H.; Izzo, A. Effectiveness and Safety of Ginger in the Treatment of PregnancyInduced Nausea and Vomiting. Obstet. Gynecol. 2005, 105, 849-856. [CrossRef]

147. Chaiyakunapruk, N.; Kitikannakorn, N.; Nathisuwan, S.; Leeprakobboon, K.; Leelasettagool, C. The efficacy of ginger for the prevention of postoperative nausea and vomiting: A meta-analysis. Am. J. Obstet. Gynecol. 2006, 194, 95-99. [CrossRef] [PubMed]

148. Ernst, E.; Pittler, M.H. Efficacy of ginger for nausea and vomiting: A systematic review of randomized clinical trials. Br. J. Anaesth. 2000, 84, 367-371. [CrossRef]

149. Jewell, D.; Young, G. Interventions for nausea and vomiting in early pregnancy. Cochrane Database Syst. Rev. 2010, CD000145. [CrossRef]

150. Manusirivithaya, S.; Sripramote, M.; Tangjitgamol, S.; Sheanakul, C.; Leelahakorn, S.; Thavaramara, T.; Tangcharoenpanich, K. Antiemetic effect of ginger in gynecologic oncology patients receiving cisplatin. Int. J. Gynecol. Cancer 2004, 14, 1063-1069. [CrossRef]

151. Altman, R.D.; Marcussen, K.C. Effects of a ginger extract on knee pain in patients with osteoarthritis. Arthritis Rheum. 2001, 44, 2531-2538. [CrossRef]

152. Bliddal, H.; Rosetzsky, A.; Schlichting, P.; Weidner, M.; Andersen, L.; Ibfelt, H.-H.; Christensen, K.; Jensen, O.; Barslev, J. A randomized, placebo-controlled, cross-over study of ginger extracts and Ibuprofen in osteoarthritis. Osteoarthr. Cartil. 2000, 8 , 9-12. [CrossRef]

153. Srivastava, K.; Mustafa, T. Ginger (Zingiber officinale) in rheumatism and musculoskeletal disorders. Med. Hypotheses 1992, 39, 342-348. [CrossRef]

154. Ilkhanizadeh, B.; Shirpoor, A.; Ansari, M.H.K.; Nemati, S.; Rasmi, Y. Protective Effects of Ginger (Zingiber officinale) Extract against Diabetes-Induced Heart Abnormality in Rats. Diabetes Metab. J. 2016, 40, 46-53. [CrossRef]

155. Akbari, A.; Nasiri, K.; Heydari, M.; Mosavat, S.H.; Iraji, A. The Protective Effect of Hydroalcoholic Extract of Zingiber officinale Roscoe (Ginger) on Ethanol-Induced Reproductive Toxicity in Male Rats. J. Evid. Based Integr. Med. 2017, 22, 609-617. [CrossRef]

156. Golbitz, P. Traditional soyfoods: Processing and products. J. Nutr. 1995, 125, 570-572.

157. Lee, G.-A.; Crawford, G.W.; Liu, L.; Sasaki, Y.; Chen, X. Archaeological Soybean (Glycine max) in East Asia: Does Size Matter? PLoS ONE 2011, 6, e26720. [CrossRef] [PubMed]

158. Abuajah, C.I.; Ogbonna, A.C.; Osuji, C.M. Functional components and medicinal properties of food: A review. J. Food Sci. Technol. 2015, 52, 2522-2529. [CrossRef] [PubMed] 
159. Hooper, L.; Ryder, J.; Kurzer, M.; Lampe, J.; Messina, M.; Phipps, W.; Cassidy, A. Effects of soy protein and isoflavones on circulating hormone concentrations in pre- and post-menopausal women: A systematic review and meta-analysis. Hum. Reprod. Updat. 2009, 15, 423-440. [CrossRef]

160. Kohama, T.; Kobayashi, H.; Inoue, M. The Effect of Soybeans on the Anovulatory Cycle. J. Med. Food 2005, 8, 550-551. [CrossRef]

161. Tokede, O.A.; Onabanjo, T.A.; Yansane, A.; Gaziano, J.M.; Djoussé, L. Soya products and serum lipids: A meta-analysis of randomised controlled trials. Br. J. Nutr. 2015, 114, 831-843. [CrossRef]

162. Song, X.; Zeng, R.; Ni, L.; Liu, C. The effect of soy or isoflavones on homocysteine levels: A meta-analysis of randomised controlled trials. J. Hum. Nutr. Diet. 2016, 29, 797-804. [CrossRef]

163. Llaneza, P.; González, C.; Fernandez-Iñarrea, J.; Alonso, A.; Diaz, F.; Arnott, I.; Ferrer-Barriendos, J. Soy isoflavones, diet and physical exercise modify serum cytokines in healthy obese postmenopausal women. Phytomedicine 2011, 18, 245-250. [CrossRef]

164. Høie, L.H.; Graubaum, H.-J.; Harde, A.; Gruenwald, J.; Wernecke, K.-D. Lipid-lowering effect of 2 dosages of a soy protein supplement in Hypercholesterolemia. Adv. Ther. 2005, 22, 175-186. [CrossRef]

165. Greany, K.A.; Nettleton, J.A.; Wangen, K.E.; Thomas, W.; Kurzer, M.S. Consumption of isoflavone-rich soy protein does not alter homocysteine or markers of inflammation in postmenopausal women. Eur. J. Clin. Nutr. 2007, 62, 1419-1425. [CrossRef]

166. Imani, H.; Tabibi, H.; Atabak, S.; Rahmani, L.; Ahmadinejad, M.; Hedayati, M. Effects of Soy Consumption on Oxidative Stress, Blood Homocysteine, Coagulation Factors, and Phosphorus in Peritoneal Dialysis Patients. J. Ren. Nutr. 2009, 19, 389-395. [CrossRef]

167. Jenkins, D.J.A.; Kendall, C.W.C.; Jackson, C.-J.C.; Connelly, P.W.; Parker, T.; Faulkner, D.; Vidgen, E.; Cunnane, S.C.; Leiter, L.A.; Josse, R.G. Effects of high- and low-isoflavone soyfoods on blood lipids, oxidized LDL, homocysteine, and blood pressure in hyperlipidemic men and women. Am. J. Clin. Nutr. 2002, 76, 365-372. [CrossRef]

168. Hanson, L.N.; Engelman, H.M.; Alekel, D.L.; Schalinske, K.L.; Kohut, M.L.; Reddy, M.B. Effects of soy isoflavones and phytate on homocysteine, C-reactive protein, and iron status in postmenopausal women. Am. J. Clin. Nutr. 2006, 84, 774-780. [CrossRef]

169. Reimann, M.; Dierkes, J.; Carlsohn, A.; Talbot, D.; Ferrari, M.; Hallund, J.; Hall, W.L.; Vafeiadou, K.; Huebner, U.; Branca, F.; et al Consumption of Soy Isoflavones Does Not Affect Plasma Total Homocysteine or Asymmetric Dimethylarginine Concentrations in Healthy Postmenopausal Women. J. Nutr. 2006, 136, 100-105. [CrossRef]

170. Brandão, L.C.; Hachul, H.; Bittencourt, L.R.; Baracat, E.C.; Tufik, S.; D'Almeida, V. Effects of isoflavone on oxidative stress parameters and homocysteine in postmenopausal women complaining of insomnia. Biol. Res. 2009, 42, 281-287. [CrossRef]

171. Snelson, M.; Mamo, J.C.L.; Lam, V.; Giles, C.; Takechi, R. Differential Effects of High-Protein Diets Derived from Soy and Casein on Blood-Brain Barrier Integrity in Wild-type Mice. Front. Nutr. 2017, 4, 35. [CrossRef]

172. Adam, S.K.; Das, S.; Soelaiman, I.N.; Umar, N.A.; Jaarin, K. Consumption of Repeatedly Heated Soy Oil Increases the Serum Parameters Related to Atherosclerosis in Ovariectomized Rats. Tohoku J. Exp. Med. 2008, 215, 219-226. [CrossRef]

173. Kumar, K.B.H.; Sabu, M.C.; Lima, P.S.; Kuttan, R. Modulation of Haematopoetic System and Antioxidant Enzymes by Emblica Officinalis Gaertn and its Protective Role Against $\gamma$-radiation Induced Damages in Mice. J. Radiat. Res. 2004, 45, 549-555. [CrossRef]

174. Singh, I.; Sharma, A.; Nunia, V.; Goyal, P.K. Radioprotection of Swiss albino mice by Emblica officinalis. Phytother. Res. 2005, 19, 444-446. [CrossRef]

175. Singh, I.; Soyal, D.; Goyal, P.K. Emblica officinalis (Linn.) Fruit Extract Provides Protection against Radiation-Induced Hematological and Biochemical Alterations in Mice. J. Environ. Pathol. Toxicol. Oncol. 2006, 25, 643-654. [CrossRef]

176. Kim, H.Y.; Yokozawa, T.; Tohda, C.; Rao, T.P.; Juneja, L.R. Influence of Amla (Emblica officinalis Gaertn.) on Hypercholesterolemia and Lipid Peroxidation in Cholesterol-Fed Rats. J. Nutr. Sci. Vitaminol. 2005, 51, 413-418. [CrossRef]

177. Panda, S.; Kar, A. Fruit extract of Emblica officinalis ameliorates hyperthyroidism and hepatic lipid peroxidation in mice. Die Pharmazie 2003, 58, 753-755. [PubMed]

178. Rajak, S.; Banerjee, S.; Sood, S.; Dinda, A.; Gupta, Y.; Gupta, S.; Maulik, S. Emblica officinalis causes myocardial adaptation and protects against oxidative stress in ischemic-reperfusion injury in rats. Phytother. Res. 2004, 18, 54-60. [CrossRef] [PubMed]

179. Rao, T.; Sakaguchi, N.; Juneja, L.; Wada, E.; Yokozawa, T. Amla (Emblica officinalis Gaertn.) Extracts Reduce Oxidative Stress in Streptozotocin-Induced Diabetic Rats. J. Med. Food 2005, 8, 362-368. [CrossRef]

180. Yokozawa, T.; Kim, H.Y.; Okubo, T.; Chu, D.-C.; Juneja, L.R. Amla (Emblica officinalis Gaertn.) prevents dyslipidaemia and oxidative stress in the ageing process. Br. J. Nutr. 2007, 97, 1187-1195. [CrossRef] [PubMed]

181. Anilakumar, K.R.; Nagaraj, N.S.; Santhanam, K. Reduction of hexachlorocyclohexane-induced oxidative stress and cytotoxicity in rat liver by Emblica officinalis gaertn. Indian J. Exp. Biol. 2007, 45, 450-454. [PubMed]

182. Sultana, S.; Ahmad, S.; Khan, N.; Jahangir, T. Effect of Emblica officinalis (Gaertn) on CCl4 induced hepatic toxicity and DNA synthesis in Wistar rats. Indian J. Exp. Biol. 2005, 43, 430-436.

183. Sultana, S.; Ahmed, S.; Sharma, S.; Jahangir, T. Emblica officinalis reverses thioacetamide-induced oxidative stress and early promotional events of primary hepatocarcinogenesis. J. Pharm. Pharmacol. 2010, 56, 1573-1579. [CrossRef]

184. Tasduq, S.A.; Kaisar, P.; Gupta, D.K.; Kapahi, B.K.; Jyotsna, S.; Maheshwari, H.S.; Johri, R.K. Protective effect of a 50\% hydroalcoholic fruit extract of Emblica officinalis against anti-tuberculosis drugs induced liver toxicity. Phytother. Res. 2005, 19, 193-197. [CrossRef] 
185. Ram, M.S.; Neetu, D.; Yogesh, B.; Anju, B.; Dipti, P.; Pauline, T.; Sharma, S.; Sarada, S.; Ilavazhagan, G.; Kumar, D.; et al. Cytoprotective and immunomodulating properties of Amla (Emblica officinalis) on lymphocytes: An in-vitro study. J. Ethnopharmacol. 2002, 81, 5-10. [CrossRef]

186. Sai Ram, M.; Neetu, D.; Deepti, P.; Vandana, M.; Ilavazhagan, G.; Kumar, D.; Selvamurthy, W. Cytoprotective activity of Amla (Emblica officinalis) against chromium (VI) induced oxidative injury in murine macrophages. Phytother. Res. 2003, 17, 430-433. [CrossRef]

187. Mathur, R.; Sharma, A.; Dixit, V.; Varma, M. Hypolipidaemic effect of fruit juice of Emblica officinalis in cholesterol-fed rabbits. J. Ethnopharmacol. 1996, 50, 61-68. [CrossRef]

188. Brown, R.P.; Gerbarg, P.L.; Ramazanov, Z. Rhodiola rosea: A phytomedicinal overview. HerbalGram 2002, 56, 40-52.

189. Winston, D. Harmony Remedies: An Overview of Adaptogens; Herbal Therapeutics Research Library: Washington, NJ, USA, 2004.

190. Upadya, H.; Prabhu, S.; Prasad, A.; Subramanian, D.; Gupta, S.; Goel, A. A randomized, double blind, placebo controlled, multicenter clinical trial to assess the efficacy and safety of Emblica officinalis extract in patients with dyslipidemia. BMC Complement. Altern. Med. 2019, 19, 27. [CrossRef]

191. Chen, T.-S.; Liou, S.-Y.; Chang, Y.-L. Supplementation of Emblica Officinalis (Amla) Extract Reduces Oxidative Stress in Uremic Patients. Am. J. Chin. Med. 2009, 37, 19-25. [CrossRef]

192. Rainey, C.; Nyquist, L. Nuts-Nutrition and Health Benefits of Daily Use. Nutr. Today 1997, 32, 157-163. [CrossRef]

193. Segura, R.; Javierre, C.; Lizarraga, M.A.; Ros, E. Other relevant components of nuts: Phytosterols, folate and minerals. Br. J. Nutr. 2006, 96, S36-S44. [CrossRef]

194. Yang, J.; Liu, R.H.; Halim, L. Antioxidant and antiproliferative activities of common edible nut seeds. LWT 2009, 42, 1-8. [CrossRef]

195. Mercanlıgil, S.M.; Arslan, P.; Alasalvar, C.; Okut, E.; Akgül, E.; Pınar, A.; Geyik, P.Ö.; Tokgözoğlu, L.; Shahidi, F. Effects of hazelnut-enriched diet on plasma cholesterol and lipoprotein profiles in hypercholesterolemic adult men. Eur. J. Clin. Nutr. 2006, 61, 212-220. [CrossRef]

196. Morgan, J.M.; Horton, K.; Reese, D.; Carey, C.; Walker, K.; Capuzzi, D.M. Effects of Walnut Consumption as Part of a Low-Fat, Low-Cholesterol Diet on Serum Cardiovascular Risk Factors. Int. J. Vitam. Nutr. Res. 2002, 72, 341-347. [CrossRef]

197. Caramia, G. Virgin olive oil. From legend to scientific knowledge of the nutraceutical aspects. Med Surg. Pediatrics 2006, $28,9$.

198. Covas, M.-I.; Konstantinidou, V.; Fitó, M. Olive Oil and Cardiovascular Health. J. Cardiovasc. Pharmacol. 2009, 54, 477-482. [CrossRef] [PubMed]

199. Kipnis, V.; Freedman, L.S.; Brown, C.C.; Hartman, A.; Schatzkin, A.; Wacholder, S. Interpretation of Energy Adjustment Models for Nutritional Epidemiology. Am. J. Epidemiol. 1993, 137, 1376-1380. [CrossRef] [PubMed]

200. Trichopoulou, A.; Dilis, V. Olive oil and longevity. Mol. Nutr. Food Res. 2007, 51, 1275-1278. [CrossRef]

201. Trichopoulou, A.; Lagiou, P. Healthy Traditional Mediterranean Diet: An Expression of Culture, History, and Lifestyle. Nutr. Rev. 1997, 55, 383-389. [CrossRef] [PubMed]

202. Braga, C.; Vecchia, C.L.; Franceschi, S.; Negri, E.; Parpinel, M.; Decarli, A.; Giacosa, A.; Trichopoulos, D. Olive oil, other seasoning fats, and the risk of colorectal carcinoma. Cancer 1998, 82, 448-453. [CrossRef]

203. Buckland, G.; Gonzalez, C.A. The role of olive oil in disease prevention: A focus on the recent epidemiological evidence from cohort studies and dietary intervention trials. Br. J. Nutr. 2015, 113, S94-S101. [CrossRef] [PubMed]

204. Martin-Moreno, J.M.; Willett, W.C.; Gorgojo, L.; Banegas, J.R.; Rodriguez-Artalejo, F.; Fernandez-Rodriguez, J.C.; Maisonneuve, P.; Boyle, P. Dietary fat, olive oil intake and breast cancer risk. Int. J. Cancer 1994, 58, 774-780. [CrossRef]

205. Tzonou, A.; Kalandidi, A.; Trichopoulou, A.; Hsieh, C.C.; Toupadaki, N.; Willett, W.; Trichopoulos, D. Diet and coronary heart disease: A case-control study in Athens, Greece. Epidemiology 1993, 4, 511-516. [CrossRef]

206. Rodrigues, A.P.D.S.; Rosa, L.P.D.S.; Noll, M.; Silveira, E.A. Traditional Brazilian Diet and Olive Oil Reduce Cardiometabolic Risk Factors in Severely Obese Individuals: A Randomized Trial. Nutrients 2020, 12, 1413. [CrossRef]

207. Battu, S.K.; Repka, M.A.; Maddineni, S.; Chittiboyina, A.G.; Avery, M.A.; Majumdar, S. Physicochemical Characterization of Berberine Chloride: A Perspective in the Development of a Solution Dosage Form for Oral Delivery. AAPS PharmSciTech 2010, 11, 1466-1475. [CrossRef]

208. Bhutada, P.; Mundhada, Y.; Bansod, K.; Dixit, P.; Umathe, S.; Mundhada, D. Anticonvulsant activity of berberine, an isoquinoline alkaloid in mice. Epilepsy Behav. 2010, 18, 207-210. [CrossRef]

209. Domitrović, R.; Cvijanović, O.; Pernjak-Pugel, E.; Škoda, M.; Mikelić, L.; Crnčević-Orlić, Ž. Berberine exerts nephroprotective effect against cisplatin-induced kidney damage through inhibition of oxidative/nitrosative stress, inflammation, autophagy and apoptosis. Food Chem. Toxicol. 2013, 62, 397-406. [CrossRef]

210. Kulkarni, S.K.; Dhir, A. Berberine: A plant alkaloid with therapeutic potential for central nervous system disorders. Phytother. Res. 2009, 24, 317-324. [CrossRef]

211. Kumar, A.; Ekavali; Chopra, K.; Mukherjee, M.; Pottabathini, R.; Dhull, D.K. Current knowledge and pharmacological profile of berberine: An update. Eur. J. Pharmacol. 2015, 761, 288-297. [CrossRef]

212. Li, M.-H.; Zhang, Y.-J.; Yu, Y.-H.; Yang, S.-H.; Iqbal, J.; Mi, Q.-Y.; Li, B.; Wang, Z.-M.; Mao, W.-X.; Xie, H.-G.; et al. Berberine improves pressure overload-induced cardiac hypertrophy and dysfunction through enhanced autophagy. Eur. J. Pharmacol. 2014, 728, 67-76. [CrossRef] 
213. Chang, X.-X.; Yan, H.-M.; Xu, Q.; Xia, M.-F.; Bian, H.; Zhu, T.-F.; Gao, X. The effects of berberine on hyperhomocysteinemia and hyperlipidemia in rats fed with a long-term high-fat diet. Lipids Health Dis. 2012, 11, 86. [CrossRef]

214. Shidfar, F.; Ebrahimi, S.S.; Hosseini, S.; Heydari, I.; Shidfar, S.; Hajhassani, G. The Effects of Berberis vulgaris Fruit Extract on Serum Lipoproteins, apoB, apoA-I, Homocysteine, Glycemic Control and Total Antioxidant Capacity in Type 2 Diabetic Patients. Iran. J. Pharm. Res. 2012, 11, 643-652.

215. Alikiaii, B.; Bagherniya, M.; Askari, G.; Johnston, T.P.; Sahebkar, A. The role of phytochemicals in sepsis: A mechanistic and therapeutic perspective. BioFactors 2021, 47, 19-40. [CrossRef]

216. Alikiaii, B.; Bagherniya, M.; Askari, G.; Sathyapalan, T.; Sahebkar, A. Evaluation of the effect of curcumin on pneumonia: A systematic review of preclinical studies. Phytother. Res. 2020. [CrossRef]

217. Ghandadi, M.; Sahebkar, A. Curcumin: An Effective Inhibitor of Interleukin-6. Curr. Pharm. Des. 2017, 23, 921-931. [CrossRef] [PubMed]

218. Momtazi, A.A.; Derosa, G.; Maffioli, P.; Banach, M.; Sahebkar, A. Role of microRNAs in the Therapeutic Effects of Curcumin in Non-Cancer Diseases. Mol. Diagn. Ther. 2016, 20, 335-345. [CrossRef] [PubMed]

219. Panahi, Y.; Ahmadi, Y.; Teymouri, M.; Johnston, T.P.; Sahebkar, A. Curcumin as a potential candidate for treating hyperlipidemia: A review of cellular and metabolic mechanisms. J. Cell. Physiol. 2018, 233, 141-152. [CrossRef]

220. Teymouri, M.; Pirro, M.; Johnston, T.P.; Sahebkar, A. Curcumin as a multifaceted compound against human papilloma virus infection and cervical cancers: A review of chemistry, cellular, molecular, and preclinical features. BioFactors 2017, 43, 331-346. [CrossRef]

221. Iranshahi, M.; Sahebkar, A.; Hosseini, S.; Takasaki, M.; Konoshima, T.; Tokuda, H. Cancer chemopreventive activity of diversin from Ferula diversivittata in vitro and in vivo. Phytomedicine 2010, 17, 269-273. [CrossRef] [PubMed]

222. Panahi, Y.; Khalili, N.; Sahebi, E.; Namazi, S.; Simental-Mendía, L.E.; Majeed, M.; Sahebkar, A.; Simental-Mendía, L. Effects of Curcuminoids Plus Piperine on Glycemic, Hepatic and Inflammatory Biomarkers in Patients with Type 2 Diabetes Mellitus: A Randomized Double-Blind Placebo-Controlled Trial. Drug Res. 2018, 68, 403-409. [CrossRef] [PubMed]

223. Bianconi, V.; Sahebkar, A.; Atkin, S.L.; Pirro, M. The regulation and importance of monocyte chemoattractant protein-1. Curr. Opin. Hematol. 2018, 25, 44-51. [CrossRef]

224. Ghasemi, F.; Shafiee, M.; Banikazemi, Z.; Pourhanifeh, M.H.; Khanbabaei, H.; Shamshirian, A.; Moghadam, S.A.; ArefNezhad, R.; Sahebkar, A.; Avan, A.; et al. Curcumin inhibits NF-kB and Wnt/ $\beta$-catenin pathways in cervical cancer cells. Pathol. Res. Pr. 2019, 215, 152556. [CrossRef]

225. Martin, R.C.; Aiyer, H.S.; Malik, D.J.; Li, Y. Effect on pro-inflammatory and antioxidant genes and bioavailable distribution of whole turmeric vs curcumin: Similar root but different effects. Food Chem. Toxicol. 2012, 50, 227-231. [CrossRef]

226. Sahebkar, A. Why it is necessary to translate curcumin into clinical practice for the prevention and treatment of metabolic syndrome? BioFactors 2013, 39, 197-208. [CrossRef]

227. Campbell, M.S.; Ouyang, A.; Krishnakumar, I.M.; Charnigo, R.J.; Westgate, P.M.; Fleenor, B.S. Influence of enhanced bioavailable curcumin on obesity-associated cardiovascular disease risk factors and arterial function: A double-blinded, randomized, controlled trial. Nutrients 2019, 62, 135-139. [CrossRef] [PubMed]

228. Varatharajalu, R.; Garige, M.; Leckey, L.C.; Reyes-Gordillo, K.; Shah, R.; Lakshman, M.R. Protective Role of Dietary Curcumin in the Prevention of the Oxidative Stress Induced by Chronic Alcohol with respect to Hepatic Injury and Antiatherogenic Markers. Oxidative Med. Cell. Longev. 2016, 2016, 1-10. [CrossRef]

229. Madaric, A.; Kadrabova, J.; Krajcovicova-Kudlackova, M.; Valachovicova, M.; Spustova, V.; Mislanova, C.; Kajaba, I.; Blazicek, P. The effect of bioactive complex of quercetin, selenium, catechins and curcumin on cardiovascular risk markers in healthy population after a two month consumption. Bratislavske Lekarske Listy 2013, 114, 84-87. [CrossRef] [PubMed]

230. Mansouri, Z.; Sabetkasaei, M.; Moradi, F.; Masoudnia, F.; Ataie, A. Curcumin has Neuroprotection Effect on Homocysteine Rat Model of Parkinson. J. Mol. Neurosci. 2012, 47, 234-242. [CrossRef] [PubMed]

231. Jelodar, G.; Azimifar, A. Evaluation of serum cancer antigen 125, resistin, leptin, homocysteine, and total antioxidant capacity in rat model of endometriosis treated with Curcumin. Physiol. Rep. 2019, 7, e14016. [CrossRef]

232. Sahebkar, A. Effects of resveratrol supplementation on plasma lipids: A systematic review and meta-analysis of randomized controlled trials. Nutr. Rev. 2013, 71, 822-835. [CrossRef] [PubMed]

233. Sahebkar, A.; Serban, C.; Ursoniu, S.; Wong, N.D.; Muntner, P.; Graham, I.M.; Mikhailidis, D.P.; Rizzo, M.; Rysz, J.; Sperling, L.S.; et al. Lack of efficacy of resveratrol on C-reactive protein and selected cardiovascular risk factors-Results from a systematic review and meta-analysis of randomized controlled trials. Int. J. Cardiol. 2015, 189, 47-55. [CrossRef] [PubMed]

234. Abu-Amero, K.K.; Kondkar, A.A.; Chalam, K.V. Resveratrol and Ophthalmic Diseases. Nutrients 2016, 8, 200. [CrossRef]

235. Limmongkon, A.; Janhom, P.; Amthong, A.; Kawpanuk, M.; Nopprang, P.; Poohadsuan, J.; Somboon, T.; Saijeen, S.; Surangkul, D.; Srikummool, M.; et al. Antioxidant activity, total phenolic, and resveratrol content in five cultivars of peanut sprouts. Asian Pac. J. Trop. Biomed. 2017, 7, 332-338. [CrossRef]

236. Rauf, A.; Imran, M.; Suleria, H.A.R.; Ahmad, B.; Peters, D.G.; Mubarak, M.S. A comprehensive review of the health perspectives of resveratrol. Food Funct. 2017, 8, 4284-4305. [CrossRef]

237. Koz, S.T.; Etem, E.O.; Baydas, G.; Yuce, H.; Ozercan, H.I.; Kuloğlu, T.; Koz, S.; Etem, A.; Demir, N. Effects of resveratrol on blood homocysteine level, on homocysteine induced oxidative stress, apoptosis and cognitive dysfunctions in rats. Brain Res. 2012, 1484, 29-38. [CrossRef] 
238. Noll, C.; Hamelet, J.; Ducros, V.; Belin, N.; Paul, J.-L.; Delabar, J.-M.; Janel, N. Resveratrol supplementation worsen the dysregulation of genes involved in hepatic lipid homeostasis observed in hyperhomocysteinemic mice. Food Chem. Toxicol. 2009, 47, 230-236. [CrossRef]

239. Yilmaz, O.; Keser, S.; Tuzcu, M.; Çetintaş, B. Resveratrol (trans-3,4',5-trihydroxystilbene) decreases lipid peroxidation level and protects antioxidant capacity in sera and erythrocytes of old female Wistar rats induced by the kidney carcinogen potassium bromate. Environ. Toxicol. Pharmacol. 2007, 24, 79-85. [CrossRef]

240. Schroecksnadel, K.; Winkler, C.; Wirleitner, B.; Schennach, H.; Weiss, G.; Fuchs, D.; Weiss, G. Anti-inflammatory compound resveratrol suppresses homocysteine formation in stimulated human peripheral blood mononuclear cells in vitro. Clin. Chem. Lab. Med. 2005, 43, 1084-1088. [CrossRef]

241. Andreson, J. Dietary fiber: Hyperlipidemia, hypertension, and coronary heart disease. Am. J. Gastroenterol. 1986, 81, 907-909.

242. Theuwissen, E.; Mensink, R.P. Water-soluble dietary fibers and cardiovascular disease. Physiol. Behav. 2008, 94, 285-292. [CrossRef]

243. Anderson, J.W.; Baird, P.; Davis, R.H.; Ferreri, S.; Knudtson, M.; Koraym, A.; Waters, V.; Williams, C.L. Health benefits of dietary fiber. Nutr. Rev. 2009, 67, 188-205. [CrossRef]

244. Wood, R.J.; Volek, J.S.; Davis, S.R.; Dell'Ova, C.; Fernandez, M.L. Effects of a carbohydrate-restricted diet on emerging plasma markers for cardiovascular disease. Nutr. Metab. 2006, 3, 19. [CrossRef]

245. Sprecher, D.L.; Pearce, G.L. Fiber-multivitamin combination therapy: A beneficial influence on low-density lipoprotein and homocysteine. Metabolism 2002, 51, 1166-1170. [CrossRef] 